Article

\title{
Effect of Site Specific Nitrogen Management on Seed Nitrogen-A Driving Factor of Winter Oilseed Rape (Brassica napus L.) Yield
}

\author{
Remigiusz Łukowiak*(D) and Witold Grzebisz \\ Department of Agricultural Chemistry and Environmental Biogeochemistry, Poznan University of Life Sciences, \\ Wojska Polskiego 28, 60-637 Poznan, Poland; witold.grzebisz@up.poznan.pl \\ * Correspondence: remigiusz.lukowiak@up.poznan.pl; Tel.: +48-61-846-6287
}

Received: 31 July 2020; Accepted: 7 September 2020; Published: 10 September 2020

check for updates

\begin{abstract}
It has been assumed that the management of both soil and fertilizer $\mathrm{N}$ in winter oilseed rape (WOSR) is crucial for $\mathrm{N}$ accumulation in seeds $\left(\mathrm{N}_{\mathrm{se}}\right)$ and yield. This hypothesis was evaluated based on field experiments conducted in 2008/09, 2009/10, 2010/11 seasons, each year at two sites, differing in soil fertility, including indigenous $\mathrm{N}\left(\mathrm{N}_{\mathrm{i}}\right)$ supply. The experimental factors consisted of two $\mathrm{N}$ fertilizers: $\mathrm{N}$ and $\mathrm{NS}$, and four $\mathrm{N}_{\mathrm{f}}$ rates: $0,80,120,160 \mathrm{~kg} \mathrm{ha}^{-1}$. Yield, as governed by site $\times \mathrm{N}_{\mathrm{f}}$ rate interaction, responded linearly to $\mathrm{N}_{\text {se }}$ at harvest. The maximum $\mathrm{N}_{\text {se }}\left(\mathrm{N}_{\text {semax }}\right)$, as evaluated by $\mathrm{N}$ input $\left(\mathrm{N}_{\mathrm{in}}=\mathrm{N}_{\mathrm{i}}+\mathrm{N}_{\mathrm{f}}\right)$ to WOSR at spring regrowth, varied from 95 to $153 \mathrm{~kg} \mathrm{ha}^{-1}$, and determined $80 \%$ of yield variability. The basic reason of site diversity in $\mathrm{N}_{\text {semax }}$ was $\mathrm{N}_{\mathrm{i}}$ efficiency, ranging from $46 \%$ to $70 \%$, respectively. The second cause of $\mathrm{N}_{\text {se }}$ variability was a shortage of $\mathrm{N}$ supply from +9.5 soil to $-8.8 \mathrm{~kg} \mathrm{ha}^{-1}$ to the growing seeds during the seed filling period (SFP). This $\mathrm{N}$ pool supports the $\mathrm{N}$ concentration in seeds, resulting in both seed density and a seed weight increase, finally leading to a yield increase.
\end{abstract}

Keywords: seed density; $\mathrm{N}$ uptake; indices of $\mathrm{N}$ productivity; mineral $\mathrm{N}$; indigenous $\mathrm{N}_{\min }$ at spring; post-harvest $\mathrm{N}_{\min } ; \mathrm{N}$ balance; $\mathrm{N}$ efficiency

\section{Introduction}

Over the last four decades, oilseed rape (Brassica napus L., OSR) has become one of the most important global oil crops. The main reason for the rise in OSR production was an intensive breeding progress, resulting in new double 00 varieties which deliver plant oil of high consumption value [1,2]. Between 2009-2018, the world OSR harvested area increased from 31 million (mln) to $37 \mathrm{mln}$ ha. The world average yield for this period increased to about $2.0 \mathrm{t} \mathrm{ha}^{-1}$, being only slightly lower than that recorded recently in Canada (2.2 $\left.\mathrm{t} \mathrm{ha}^{-1}\right)$ [3]. The leading producers of OSR are Canada, China, and the European Union (EU). Canada, which delivers about $25 \%$ of the world rapeseed production, increased the sown area of this crop from $6.5 \mathrm{mln}$ ha in 2009 to $9.1 \mathrm{mln}$ ha in 2018 [3,4]. In the EU, the leading producers of winter oilseed rape (WOSR) are Germany, France, and Poland. Seed yields in these countries, in spite of high breeding progress, stagnated in the period extending from 2009 to $2018[3,5]$.

The main constraints in WOSR production in the EU are weather conditions during the growing season and soil fertility level [6]. The resistance of WOSR to frost does not depend only on temperatures during winter but also on plants' physiological status just before winter, which significantly affects plant density $[7,8]$. Two basic yield components, i.e., seed density (SD, number of seed per $\mathrm{m}^{2}$ ) and seed weight (thousand seed weight, TSW, g) are responsible for the final yield of WOSR. The first, dominant component is SD, which is indirectly defined by plant density, number of pods (pod density, PD, 
pods per $\mathrm{m}^{2}$ ) [9]. The critical period of yield formation, referring to the development of primary yield components, such as inflorescences and succeeding pods, extends from the budding stage up to the pod full size [10]. One of the most specific characteristics of the yield development of WOSR is a strong compensation mechanism, occurring between yield components during the period extending from the onset of flowering towards the end of seed growth, i.e., maturity [11]. As reported by Berry and Spink [12], the amount of water required by WOSR during this period to exploit its yielding potential is $300 \mathrm{~mm}$. Any unfavorable weather conditions during the spring vegetation lead to disturbance in the development of yield components (PD and SD). Weather disturbance during pod and seed growth negatively affects TSW [13,14].

The key nutrient responsible for yield formation by WOSR is nitrogen $(\mathrm{N})[15,16]$. This nutrient affects the number of inflorescences, flowers, and finally pods and seeds. A balanced structure of yield components depends on synchronization of a crop $\mathrm{N}$ requirement with its supply from both soil and applied fertilizers $[17,18]$. In practice, $\mathrm{N}$ supply to a given crop is, in general, oriented on the amount applied in fertilizers without considering soil resources. As a result of this fertilization strategy, $\mathrm{N}$ fertilizer productivity is highly variable, being both in shortage or in excess with respect to WOSR requirements during the critical stages of yield formation, leading in both cases to yield reduction $[16,19]$. In some EU countries like Germany and the Netherlands, the N fertilization strategy of crop plants is based on the measurement of the content of mineral $\mathrm{N}\left(\mathrm{N}_{\min }\right)$ before the spring WOSR regrowth [20]. This strategy, as has been documented recently, clearly shows that $\mathrm{N}$ use efficiency (NUE) depends not only on the $\mathrm{N}_{\min }$ content in the root zone, but also on the content of 16 other nutrients, like $\mathrm{P}, \mathrm{K}$, and $\mathrm{Mg}$, being responsible for both $\mathrm{N}$ uptake, and its utilization by plants [21-24]. Any shortage of this set of nutrients at the onset of flowering and during the seed filling period (SFP) leads to yield depression [11,25].

In spite of the extensive study on N supply to WOSR, and its impact on the development of yield components, the yield prognosis based on $\mathrm{N}_{\min }$ content is good, but not satisfactory. The black box in the effective management of $\mathrm{N}$ during the growing season of WOSR is a lack of knowledge on $\mathrm{N}$ release from its soil resources during the spring vegetation [26]. The main reason for the necessity of the $\mathrm{N}_{\mathrm{f}}$ rate optimization is a huge variability in soil potential for release of $\mathrm{N}_{\min }$, both in the period preceding the spring vegetation and during the full season of WOSR growth [23]. The key question remains, however, to what extent does the development of basic yield components depend on the indigenous resources of $\mathrm{N}$ during WOSR spring vegetation? Is the soil $\mathrm{N}$ supply at the onset of flowering to WOSR plants sufficient to meet the requirements of the growing pods and seeds? The scientific problem focuses on the impact of three $\mathrm{N}$ sources, i.e., (i) $\mathrm{N}$ mineral soil resources, indigenous $\mathrm{N}\left(\mathrm{N}_{\mathrm{i}}\right)$ at the beginning of spring WOSR vegetation; (ii) the optimum $\mathrm{N}_{\mathrm{f}}$ rate; and (iii) the quantity of the soil $\mathrm{N}_{\text {min }}$ released during the spring vegetation on the degree of WOSR yield components expression, i.e., on the sink capacity development as a prerequisite of high seed yield achievement.

The objective of the study was to define the impact of site-specific variability in in-season $\mathrm{N}$ management during the WOSR growing season based on the amount of $\mathrm{N}$ accumulated in seeds, and its relationship with the final yield.

\section{Materials and Methods}

\subsection{Experiments Set Up}

Three series of field experiments with winter oilseed rape (Brassica napus L.) were conducted during the 2008/09, 2009/10, and 2010/11 seasons. Each year, two different fields (sites) were investigated. Field experiments were conducted on soils with texture ranging from sand/sandy loam to sandy clay loam, classified as Albic Luvisol. The content of the available nutrients (measured each year just after a fore-crop harvesting from two soil depths of 0.0-0.3, and 0.3-0.6 m) ranged, depending on the nutrient, from low to very high, and it was, in general, sufficiently high for covering the nutrient requirements of the high-yielding WOSR (Table 1). 
Table 1. Soil agrochemical properties before WOSR sowing in consecutive study years.

\begin{tabular}{|c|c|c|c|c|c|c|c|c|c|c|}
\hline \multirow{2}{*}{ Year } & \multirow{2}{*}{$\begin{array}{l}\text { Site/Location } \\
\text { (Acronym) }\end{array}$} & \multirow{2}{*}{ Variety } & \multirow{2}{*}{$\begin{array}{c}\text { Soil Textural Class/ } \\
\text { Agronomy Class }\end{array}$} & \multirow{2}{*}{$\begin{array}{c}\text { pH } \\
(1 \mathrm{M} \mathrm{KCl})\end{array}$} & \multirow{2}{*}{$\begin{array}{c}\text { Organic } \\
\text { Matter }^{1}, \\
\mathrm{~g} \mathrm{~kg}^{-1} \text { Soil }\end{array}$} & $\mathrm{P}_{2} \mathrm{O}_{5}{ }^{2}$ & $\mathrm{~K}_{2} \mathrm{O}^{2}$ & $\mathrm{Mg}^{3}$ & $\mathrm{~S}^{-\mathrm{SO}_{4}}{ }^{4}$ & \multirow{2}{*}{$\frac{\mathrm{N}_{\text {min }}{ }^{5}}{\mathrm{~kg} \mathrm{ha}^{-1}}$} \\
\hline & & & & & & \multicolumn{4}{|c|}{$\mathrm{mg} \mathrm{kg}^{-1}$ Soil } & \\
\hline \multirow{2}{*}{2009} & $\begin{array}{l}\text { Gostyń (Go) } \\
51^{\circ} 52^{\prime} 06^{\prime \prime} \mathrm{N} \\
16^{\circ} 51^{\prime} 55^{\prime \prime} \mathrm{E}\end{array}$ & Californium & $\begin{array}{l}\text { Loamy sand } \\
\text { Light }\end{array}$ & $6.0 / 5.7^{6}$ & $11 / 7$ & $\begin{array}{l}149 / 124 \\
\mathrm{M} / \mathrm{M}^{8}\end{array}$ & $\begin{array}{c}249 / 123 \\
\mathrm{VH} / \mathrm{M}\end{array}$ & $\begin{array}{l}46 / 60 \\
\mathrm{M} / \mathrm{H}\end{array}$ & $\begin{array}{l}5.6 / 7.5 \\
\mathrm{~L} / \mathrm{M}\end{array}$ & $58.4 / 50.8$ \\
\hline & $\begin{array}{c}\text { Kołaczkowo }(\mathrm{Ko}) \\
52^{\circ} 13^{\prime} 00^{\prime \prime} \mathrm{N} \\
17^{\circ} 37^{\prime} 33^{\prime \prime} \mathrm{E}\end{array}$ & Nelson & $\begin{array}{c}\text { Sand/ } \\
\text { loamy sand/ } \\
\text { Very light/light }\end{array}$ & $6.2 / 6.4$ & $9 / 6$ & $\begin{array}{c}127 / 68 \\
\mathrm{M} / \mathrm{L}\end{array}$ & $\begin{array}{c}154 / 175 \\
\mathrm{H} / \mathrm{H}\end{array}$ & $\begin{array}{c}86 / 80 \\
\mathrm{VH} / \mathrm{VH}\end{array}$ & $\begin{array}{l}8.1 / 7.7 \\
\mathrm{M} / \mathrm{M}\end{array}$ & $32.4 / 27.3$ \\
\hline \multirow{2}{*}{2010} & $\begin{array}{l}\text { Buszewo }(\mathrm{Bu}) \\
51^{\circ} 32^{\prime} 41^{\prime \prime} \mathrm{N} \\
16^{\circ} 22^{\prime} 11^{\prime \prime} \mathrm{E}\end{array}$ & Californium & $\begin{array}{l}\text { Sand clay loam } \\
\text { Medium }\end{array}$ & $6.6 / 6.4$ & $13 / 5$ & $\begin{array}{l}\text { 264/262 } \\
\text { VH/VH }\end{array}$ & $\begin{array}{c}138 / 86 \\
\mathrm{M} / \mathrm{L}\end{array}$ & $\begin{array}{c}\text { 95/83 } \\
\mathrm{VH} / \mathrm{H}\end{array}$ & $\begin{array}{l}9.5 / 8.6 \\
\mathrm{M} / \mathrm{M}\end{array}$ & $40.3 / 25.7$ \\
\hline & $\begin{array}{c}\text { Wieszczyczyn (Wi) } \\
51^{\circ} 02^{\prime} 03^{\prime \prime} \mathrm{N} \\
17^{\circ} 05^{\prime} 38^{\prime \prime} \mathrm{E} \\
\end{array}$ & Nemax & $\begin{array}{l}\text { Loamy sand/ } \\
\text { sandy loam } \\
\text { Light }\end{array}$ & $5.8 / 6.0$ & $12 / 7$ & $\begin{array}{l}\text { 265/227 } \\
\text { VH/VH }\end{array}$ & $\begin{array}{c}138 / 65 \\
\mathrm{M} / \mathrm{L}\end{array}$ & $\begin{array}{l}57 / 42 \\
\mathrm{H} / \mathrm{M}\end{array}$ & $\begin{array}{l}8.5 / 7.6 \\
\mathrm{M} / \mathrm{M}\end{array}$ & $34.8 / 14.2$ \\
\hline \multirow{2}{*}{2011} & $\begin{array}{l}\text { Wenecja (Ve) } \\
51^{\circ} 48^{\prime} 45^{\prime \prime} \mathrm{N} \\
17^{\circ} 45^{\prime} 51^{\prime \prime} \mathrm{E}\end{array}$ & Californium & $\begin{array}{c}\text { Sandy loam/ } \\
\text { loam } \\
\text { Medium }\end{array}$ & $5.6 / 5.6$ & $16 / 12$ & $\begin{array}{c}\text { 121/103 } \\
\mathrm{M} / \mathrm{M}\end{array}$ & $\begin{array}{c}116 / 82 \\
\mathrm{~L} / \mathrm{L}\end{array}$ & $\begin{array}{c}85 / 74 \\
\mathrm{H} / \mathrm{H}\end{array}$ & $\begin{array}{c}12.3 / 12.2 \\
\mathrm{H} / \mathrm{H}\end{array}$ & $64.8 / 40.2$ \\
\hline & $\begin{array}{c}\text { Donatowo (Do) } \\
51^{\circ} 04^{\prime} 51^{\prime \prime} \mathrm{N} \\
16^{\circ} 51^{\prime} 37^{\prime \prime} \mathrm{E}\end{array}$ & $\begin{array}{l}\text { ES Mercure } \\
\text { F1 }\end{array}$ & $\begin{array}{l}\text { Loamy sand } \\
\text { Light }\end{array}$ & $6.3 / 6.2$ & $12 / 6$ & $\begin{array}{c}\text { 172/149 } \\
\mathrm{H} / \mathrm{M}\end{array}$ & $\begin{array}{c}204 / 150 \\
\mathrm{VH} / \mathrm{M}\end{array}$ & $\begin{array}{l}53 / 44 \\
\mathrm{H} / \mathrm{M}\end{array}$ & $\begin{array}{c}7.2 / 6.4 \\
\mathrm{M} / \mathrm{M}\end{array}$ & $35.3 / 19.7$ \\
\hline
\end{tabular}

Methods of available nutrients determination: ${ }^{1}$ loss of ignation; ${ }^{2}$ Egner-Riehm method; ${ }^{3}$ Schachtschabel method; ${ }^{4,1}$ nephelometric method of Bardsley $[27]{ }^{5} 0.01 \mathrm{M} \mathrm{CaCl} 2$ solution (soil/solution ratio $1: 5 ; \mathrm{m} / \mathrm{v}){ }^{6}$ Soil layers: $0.0-0.3 / 0.3-0.6 \mathrm{~m} ;{ }^{7}$ Soil agronomy class; ${ }^{8}$ classes of available nutrient content: $\mathrm{L}-$ low, $\mathrm{M}-\mathrm{medium}, \mathrm{H}-\mathrm{high}, \mathrm{VH}-\mathrm{very}$ high. 
The local climate, classified as intermediate between Atlantic and Continental, is seasonally variable (Table 2). Precipitation during the period extending from January to July was for most of the sites slightly higher than the long-term average, which amounted to $347.5 \mathrm{~mm}$. Each year, the highest amount of precipitation was recorded in July. In 2010, a severe shortage of precipitation was recorded in June, a critical month with respect to pods and seed growth [14], but it was preceded by high precipitation in May. Air temperatures were, with the exception of Wieszczyczyn in 2010, around the long-term average.

\subsection{Experimental Design}

The field experiment was a balanced $2 \times 4$ factorial trial conducted on two different sites each year. The first factor was the type of $\mathrm{N}$ fertilizer: (i) ammonium nitrate, 34-0-0, (ii) ammonium saltpeter with ammonium sulfur, 32-0-0-5. The second factor was composed of three rates of nitrogen/sulfur plus absolute N/S control. The arrangement of the 2 nd factor was as follows:

(1) Control-PK $+0 \mathrm{~N}+0.00 \mathrm{~kg} \mathrm{~S}$ ha;

(2) $\mathrm{PK}+80 \mathrm{~kg} \mathrm{~N} \mathrm{ha}^{-1}+12.50 \mathrm{~kg} \mathrm{Sha}^{-1}$;

(3) $\mathrm{PK}+120 \mathrm{~kg} \mathrm{~N} \mathrm{ha}^{-1}+18.75 \mathrm{~kg} \mathrm{Sha}^{-1}$;

(4) $\mathrm{PK}+160 \mathrm{~kg} \mathrm{~N} \mathrm{ha}^{-1}+25.00 \mathrm{~kg} \mathrm{Sha}^{-1}$.

The first $\mathrm{N}$ or NS rate of $80 \mathrm{~kg} \mathrm{~N}$ ha $^{-1}$, together with the respective amount of S, was applied before WOSR spring regrowth. The second $\mathrm{N}$ rate of 40 or $80 \mathrm{~kg} \mathrm{ha}^{-1}$ was applied at the end of March or the beginning of April. Amounts of applied phosphorus (P) and potassium (K) fertilizers were adjusted to the actual status of $\mathrm{P}$ and $\mathrm{K}$ soil fertility level, and applied before WOSR sowing. $\mathrm{P}$ was used as di-ammonium phosphate $\left(18 \% \mathrm{~N}, 46 \% \mathrm{P}_{2} \mathrm{O}_{5}\right)$, and $\mathrm{K}$ as muriate of potash $\left(60 \% \mathrm{~K}_{2} \mathrm{O}\right)$. The size of an individual experimental plot was $400 \mathrm{~m}^{2}(9 \times 44.4 \mathrm{~m})$ The fore-crop for WOSR at all sites was winter wheat. Standard tillage technology was applied for soil preparation for WOSR. Immediately after the winter wheat harvest, phosphorus and potassium fertilizers were broadcast on the entire field and shallow stubble ploughing (10-12 cm) + harrowing was done. Two or three weeks later, depending on the planned sowing date, a standard ploughing to a depth of $25 \mathrm{~cm}$ was done with simultaneous soil compaction with a Cambell roller. Seedbed preparation and seeding was conducted immediately after ploughing. The amount of seeds, based on 1000 seed weight, was adjusted to reach a plant density at emergence of $40-50$ plants $\mathrm{m}^{-2}$. The row spacing was 12.5 or $25 \mathrm{~cm}$, depending on the farm equipment. A robust program to control all weeds, pests, and diseases was employed in accordance with standard farm practice during the growing season, following integrated pest management (IPM) principles. In order to achieve a homogenous stage of seed maturation (seed moisture of $8 \%$ ), desiccants were applied. Harvest was performed the earliest seven days later by a combine harvester from an area of $300 \mathrm{~m}^{2}$. 
Table 2. Main characteristics of meteorological conditions during the study on the background of the long-term averages.

\begin{tabular}{|c|c|c|c|c|c|c|c|c|c|c|c|c|c|c|c|}
\hline Year & Site & $\begin{array}{l}\text { Meteorological } \\
\text { Characteristics }\end{array}$ & August & September & October & November & December & January & February & March & April & May & June & July & $\begin{array}{c}\text { Total }{ }^{1} / \\
\text { Average }\end{array}$ \\
\hline \multirow{4}{*}{2009} & Go & ${ }^{2} \mathrm{P}, \mathrm{mm}$ & 95.5 & 18.0 & 64.2 & 24.2 & 30.0 & 24.5 & 45.3 & 48.5 & 7.7 & 70.0 & 91.0 & 81.0 & 368.0 \\
\hline & & ${ }^{3} \mathrm{~T} .{ }^{\circ} \mathrm{C}$ & 18.3 & 13.2 & 9.1 & 5.6 & 1.4 & -3.1 & 0.1 & 4.2 & 11.9 & 13.1 & 15.7 & 19.0 & 8.7 \\
\hline & Ko & P. mm & 60.4 & 20.9 & 67.5 & 22.8 & 16.2 & 20.6 & 25.7 & 50.5 & 2.1 & 85.4 & 101.5 & 105.3 & 391.1 \\
\hline & & T. ${ }^{\circ} \mathrm{C}$ & 18.9 & 13.3 & 9.0 & 5.3 & 1.1 & -3.4 & -0.1 & 3.4 & 11.0 & 13.4 & 15.7 & 19.6 & 8.5 \\
\hline \multirow{4}{*}{2010} & $\mathbf{B u}$ & P. mm & 109.6 & 52.4 & 76.6 & 43.2 & 41.1 & 43.6 & 20.0 & 57.6 & 39.8 & 92.3 & 18.1 & 109.6 & 381.0 \\
\hline & & T. ${ }^{\circ} \mathrm{C}$ & 18.2 & 12.4 & 6.2 & 4.4 & -5.6 & -6.3 & -0.4 & 4.4 & 10.0 & 12.5 & 18.7 & 21.6 & 8.6 \\
\hline & Wi & P. mm & 31.9 & 58.2 & 62.8 & 40.3 & 49.1 & 19.1 & 15.3 & 38.5 & 33.4 & 83.6 & 21.2 & 121.6 & 332.7 \\
\hline & & T. ${ }^{\circ} \mathrm{C}$ & 19.1 & 16.4 & 7.2 & 6.5 & -1.4 & -7.3 & -1.2 & 4.2 & 9.1 & 11.4 & 16.9 & 22.3 & 7.9 \\
\hline \multirow{4}{*}{2011} & $\mathrm{Ve}$ & P. $\mathrm{mm}$ & 96.8 & 25.5 & 57.3 & 19.4 & 22.6 & 19.0 & 25.7 & 57.1 & 1.2 & 66.2 & 70.6 & 116.5 & 356.3 \\
\hline & & T. ${ }^{\circ} \mathrm{C}$ & 18.1 & 12.6 & 8.6 & 4.7 & 0.6 & -3.8 & -0.6 & 3.0 & 10.6 & 12.8 & 15.1 & 18.8 & 8.0 \\
\hline & Do & P. $\mathrm{mm}$ & 109.8 & 88.8 & 9.1 & 86.8 & 36.8 & 27.4 & 18.5 & 22.6 & 10.1 & 29.8 & 67.8 & 109.2 & 285.4 \\
\hline & & T. ${ }^{\circ} \mathrm{C}$ & 17.4 & 13.1 & 6.3 & 6.1 & 3.4 & 1.1 & -3.5 & 2.4 & 7.9 & 14.8 & 18.8 & 17.6 & 8.4 \\
\hline \multirow{2}{*}{$\begin{array}{l}\text { Long-term }{ }^{4} \\
1961\end{array}$} & \multirow{2}{*}{2009} & P. mm & 66.7 & 48.8 & 42.0 & 45.3 & 48.4 & 40.1 & 32.6 & 40.1 & 38.1 & 56.7 & 62.7 & 77.2 & 347.5 \\
\hline & & T. ${ }^{\circ} \mathrm{C}$ & 17.5 & 13.3 & 8.6 & 3.6 & 0 & -1.6 & -0.5 & 2.9 & 7.9 & 13.2 & 16.4 & 18.1 & 8.1 \\
\hline
\end{tabular}

${ }^{1}$ January-July; ${ }^{2}$ Precipitation; ${ }^{3}$ Temperature; ${ }^{4}$ Poznan-Ławica Meteorological Station. 


\subsection{Source of Primary Materials}

Plant materials for the determination of dry matter and measurement of $\mathrm{N}$ concentration were collected from an area of $1.0 \mathrm{~m}^{2}$ at $\mathrm{BBCH} 89$ (maturity-nearly all pods are ripe, with dark, hard seeds). Plant samples were taken from the same sowing rows across a particular experimental block. The harvested plant sample was partitioned into a sub-sample of seeds, and post-harvest residues (stem, fallen + remaining leaves, and threshed pods). At the stage of $\mathrm{BBCH} 89$, three yield components were analyzed: (i) the number of pods per $\mathrm{m}^{2}$ (pod density, PD), (ii) the number of seeds per pod, $\mathrm{Se} / \mathrm{PD}$; (iii) the thousand-seed weight (TSW, g). The number of seeds per $\mathrm{m}^{2}$ (seed density, SD) was calculated based on the first two components. Nitrogen concentration $\left(\mathrm{N}_{\mathrm{c}}\right)$ in the plant samples was determined using a standard macro-Kjeldahl procedure.

The soil content of $\mathrm{NH}_{4}-\mathrm{N}$ and $\mathrm{NO}_{3}-\mathrm{N}$ was determined in field-fresh (not air dried) soil samples within $24 \mathrm{~h}$ after sampling. Twenty-gram soil samples were shaken for $1 \mathrm{~h}$ with $100 \mathrm{~mL}$ of $0.01 \mathrm{M}$ $\mathrm{CaCl}_{2}$ solution (soil/solution ratio 1:5 m/v). Concentrations of $\mathrm{NH}_{4}-\mathrm{N}$ and $\mathrm{NO}_{3}-\mathrm{N}$ were determined by the colorimetric method using flow injection analyses (FIAstar5000, FOSS). The method of $\mathrm{NO}_{3}-\mathrm{N}$ concentration analysis consists of two basic steps: reduction from nitrate to nitrite by using a cadmium column, followed by colorimetric determination of nitrite, based on the Griess-Ilosvay reaction with $\mathrm{N}$-(1-Naphtyl) ethylene-diamine dichloride as a diazotizing agent. The measurement was performed at a wavelength of $540 \mathrm{~nm}$. To determine $\mathrm{NH}_{4}-\mathrm{N}$, a special FOSS ammonia indicator (mixture of cresol red, bromcresol purple, and bromothymol blue) was used. The measurement was made at a wavelength of $590 \mathrm{~nm}$. The total $\mathrm{N}_{\text {min }}$ was calculated as the sum of $\mathrm{NH}_{4}-\mathrm{N}$ and $\mathrm{NO}_{3}-\mathrm{N}$, and expressed in $\mathrm{kg} \mathrm{ha}^{-1}$. The $\mathrm{N}_{\min }$ content was calculated for a given soil layer, using indices which were constructed based on the soil textural class and soil bulk density [28].

\subsection{Calculated Indices/Parameters}

Based on the amount of $\mathrm{N}$ in the respective parts of WOSR plants at physiological maturity $(\mathrm{BBCH}$ 89) and in the soil before spring regrowth and after harvest, the following indices have been calculated:

A Plant and nutrient indices:

1. Harvest index: $\mathrm{HI}=\mathrm{Y} / \mathrm{TB} \cdot 100 \%$,

2. Nitrogen Harvest Index: $\mathrm{NHI}=\left(\mathrm{N}_{\mathrm{se}} / \mathrm{TN}\right) \cdot 100 \%$,

3. Partial factor productivity of $\mathrm{N}_{\mathrm{f}}: \mathrm{PFP}_{\mathrm{Nf}}=\mathrm{Y} / \mathrm{N}_{\mathrm{f}}\left(\mathrm{kg}\right.$ seeds $\mathrm{kg}^{-1} \mathrm{~N}_{\mathrm{f}}$,

4. Agronomic $\mathrm{N}$ efficiency: $A E_{\mathrm{N}}=\left(\mathrm{Y}_{\mathrm{i}}-\mathrm{Y}_{0}\right) / \mathrm{N}_{\mathrm{f}}\left(\mathrm{kg}\right.$ seeds $\left.\mathrm{kg}^{-1} \mathrm{~N}_{\mathrm{f}}\right)$,

5. Physiological $N_{f}$ efficiency: $P E_{N}=\left(Y_{i}-Y_{0}\right) /\left(T N_{i}-T N_{0}\right)\left(k g\right.$ seeds $\left.k^{-1} N_{T}\right)$,

6. Apparent $\mathrm{N}_{\mathrm{f}}$ recovery: $\mathrm{R}_{\mathrm{N}}=\left(\mathrm{TN}_{\mathrm{i}}-\mathrm{TN}_{0}\right) / \mathrm{N}_{\mathrm{f}} \cdot 100 \%$,

7. Unit Nitrogen Accumulation: $\mathrm{UNA}=\mathrm{N}_{\mathrm{se}} / \mathrm{Y}\left(\mathrm{kg} \mathrm{N} \mathrm{t}^{-1}\right.$ seeds),

8. Unit Nitrogen productivity: $\mathrm{UNP}=\mathrm{Y} / \mathrm{N}_{\mathrm{se}}\left(\mathrm{kg}\right.$ seeds $\left.\mathrm{kg} \mathrm{N} \mathrm{N}_{\mathrm{se}}\right)$,

where: $\mathrm{Y}, \mathrm{Y}_{0}, \mathrm{Y}_{\mathrm{i}}$ - seed yield, seed yield on the $\mathrm{N}$ control plot and $\mathrm{N}$ fertilized plots, $\mathrm{tha}^{-1}$ or kg $\mathrm{ha}^{-1}$; TB-total biomass— $\mathrm{tha}^{-1}$ or $\mathrm{kg} \mathrm{ha}^{-1}$; $\mathrm{TN}$-total $\mathrm{N}$ uptake, $\mathrm{kg} \mathrm{ha}^{-1} ; \mathrm{N}_{\mathrm{se}}$-amount of $\mathrm{N}$ in seeds, $\mathrm{kg} \mathrm{ha}^{-1} ; \mathrm{N}_{\mathrm{f}}-\mathrm{N}$ fertilizer rate, $\mathrm{kg} \mathrm{ha}^{-1} ; \mathrm{TN}, \mathrm{TN}_{0}, \mathrm{TN}_{\mathrm{i}}$ - total amount of $\mathrm{N}$ in WOSR at harvest for the $\mathrm{N}$ control and $\mathrm{N}$ fertilized plots.

B Soil nitrogen parameters:

1. $\mathrm{N}$ input: $\mathrm{N}_{\text {in }}=\mathrm{N}_{\text {mins }}+\mathrm{N}_{\mathrm{f}}\left(\mathrm{kg} \mathrm{ha}^{-1}\right)$,

2. Mineral $\mathrm{N}$ balance: $\mathrm{N}_{\mathrm{b}}=\mathrm{N}_{\mathrm{in}}-\mathrm{TN}\left(\mathrm{kg} \mathrm{ha}^{-1}\right)$,

3. Net $\mathrm{N}$ gain: $\mathrm{N}_{\text {gain }}=\mathrm{N}_{\text {minr }}-\mathrm{N}_{\mathrm{b}}\left(\mathrm{kg} \mathrm{ha}^{-1}\right)$,

4. Total $\mathrm{N}$ input: $\mathrm{N}_{\text {int }}=\mathrm{N}_{\text {in }}+\mathrm{N}_{\text {gain }}\left(\mathrm{kg} \mathrm{ha}^{-1}\right)$,

5. Nitrogen input efficiency: $\mathrm{NE}_{\mathrm{in}}=\mathrm{N}_{\mathrm{se}} / \mathrm{N}_{\mathrm{in}} \cdot 100 \%$,

6. Total $\mathrm{N}$ input efficiency: $\mathrm{NE}_{\text {int }}=\mathrm{N}_{\mathrm{se}} / \mathrm{N}_{\text {int }} \cdot 100 \%$,

where: $\mathrm{N}_{\text {mins }}$-the amount of mineral $\mathrm{N}$ at the WOSR spring regrowth, $\mathrm{kg} \mathrm{ha}^{-1} ; \mathrm{N}_{\text {minr }}$-the amount of mineral $\mathrm{N}$ after WOSR harvest, $\mathrm{kg} \mathrm{ha}^{-1}$. 


\subsection{Statistical Analyses}

The data were subjected to conventional analysis of variance using STATISTICA ${ }^{\circledR} 10$ (StatSoft, Krakow, Poland). The distribution of the data (normality) was checked using the Shapiro-Wilk test. The homogeneity of variance was checked by Levene's test. The differences between treatments were evaluated with Tukey's test. In the second step principal component analysis (PCA) was used to illustrate the dependence between amounts of $\mathrm{N}$ in a particular WOSR part, or in soil and yield and its components. In the third step of the diagnostic procedure, stepwise regression was applied to define an optimal set of variables for a given $\mathrm{N}$ characteristic. In the computational procedure, a consecutive variable was removed from the multiple linear regressions in a step-by-step manner. The best regression model was chosen based on the highest F-value for the model and the significance of all independent variables.

\section{Results}

\subsection{Yield and Its Components}

Yield of WOSR was significantly determined by the interaction of $\mathrm{Y} \times \mathrm{S} \times \mathrm{N}$ or by the interaction of $\mathrm{Y} \times \mathrm{F} \times \mathrm{N}_{\mathrm{f}}$ (Table 3). It is necessary to stress that weather conditions during the spring vegetation were favorable for WOSR growth. In each year of the study, the total amount of precipitation during the period extending from the onset of flowering to seed maturity (FL-SM) was below $300 \mathrm{~mm}$, as reported by Berry and Spink [12] for British conditions, but it was above the long-term average for this region in Poland $(197 \mathrm{~mm})$. The highest yield of $4.41 \mathrm{t} \mathrm{ha}^{-1}$ was obtained at Venetia with $299 \mathrm{~mm}$ of rainfall during FL-SM, directly supporting the prognosis of Berry and Spink [12]. The effect of site on yield was revealed in 2009 and 2011, and that of $\mathrm{N}_{\mathrm{f}}$ in 2010 and 2011. Based on a simple regression analysis, two distinct patterns of yield response to the increasing $\mathrm{N}_{\mathrm{f}}$ rate were observed (Table A1). The quadratic regression model, which prevailed in four sites, indicates a saturation status of $\mathrm{N}_{\mathrm{f}}$ supply with respect to the achieved yield. This conclusion is supported by the well-defined optimum $\mathrm{N}$ fertilizer rate $\left(\mathrm{N}_{\text {fop }}\right)$ for the maximum achievable yield $\left(\mathrm{Y}_{\max }\right)$ for a particular site. The calculated $\mathrm{N}_{\text {fop }}$ of 103.1, 142.7, 104.3 , and $128.0 \mathrm{~kg} \mathrm{ha}^{-1}$, resulted in a $Y_{\max }$ of $3.142,3.629,3.589$, and $4.012 \mathrm{t} \mathrm{ha}^{-1}$. The pattern of yield response to the $\mathrm{N}_{\mathrm{f}}$ rate in the other two sites, representing Wi in 2010, and Ve in 2011, fitted the linear regression model the best. This type of yield pattern clearly indicates that the applied $\mathrm{N}_{\mathrm{f}}$ rate was too low to reach the highest yield.

Total biomass of WOSR (TB) and harvest index (HI) were significantly affected by all studied factors. In 2009 and 2010, the effect of weather on TB and HI was the most pronounced. Any increase in TB resulted in a simultaneous, and at the same time, a significant drop in HI. In 2011, TB was on average much lower compared to both previous years, but HI was significantly higher $(29.8 \%$ vs. $22.6 \%$ in 2009 , and vs. $23.1 \%$ in 2010). In spite of the non-significant impact of HI on yield, a much higher yield was recorded in 2011 (Table 3).

The key yield component, i.e., SD responded significantly, as in the case of yield, to the interaction of $\mathrm{Y} \times \mathrm{S} \times \mathrm{N}$, and also to $\mathrm{Y} \times \mathrm{F} \times \mathrm{N}$. In 2009, the difference between sites reached $23.4 \%$, whereas the positive impact of NS fertilizer as compared to $\mathrm{N}$ alone was much lower, i.e., $5.2 \%$. In 2010, neither factors affected SD. In 2011, a pronounced effect on SD was exerted by the type of $\mathrm{N}_{\mathrm{f}}$ fertilizer $(+8 \%$ for $\mathrm{NS}$ versus $\mathrm{N}$ alone). The impact of site on $\mathrm{SD}$, and in consequence on yield was year-dependent. A detailed analysis of SD response to the applied $\mathrm{N}_{\mathrm{f}}$ rate clearly showed the occurrence of two regression models, i.e., quadratic and linear (Table A1), which covered the same set of sites as described previously for yield. This fact was documented by the strongest value of the correlation coefficient between yield and SD ( $r=0.84$, Table A2). 
Table 3. Yield and yield components of winter oilseed rape.

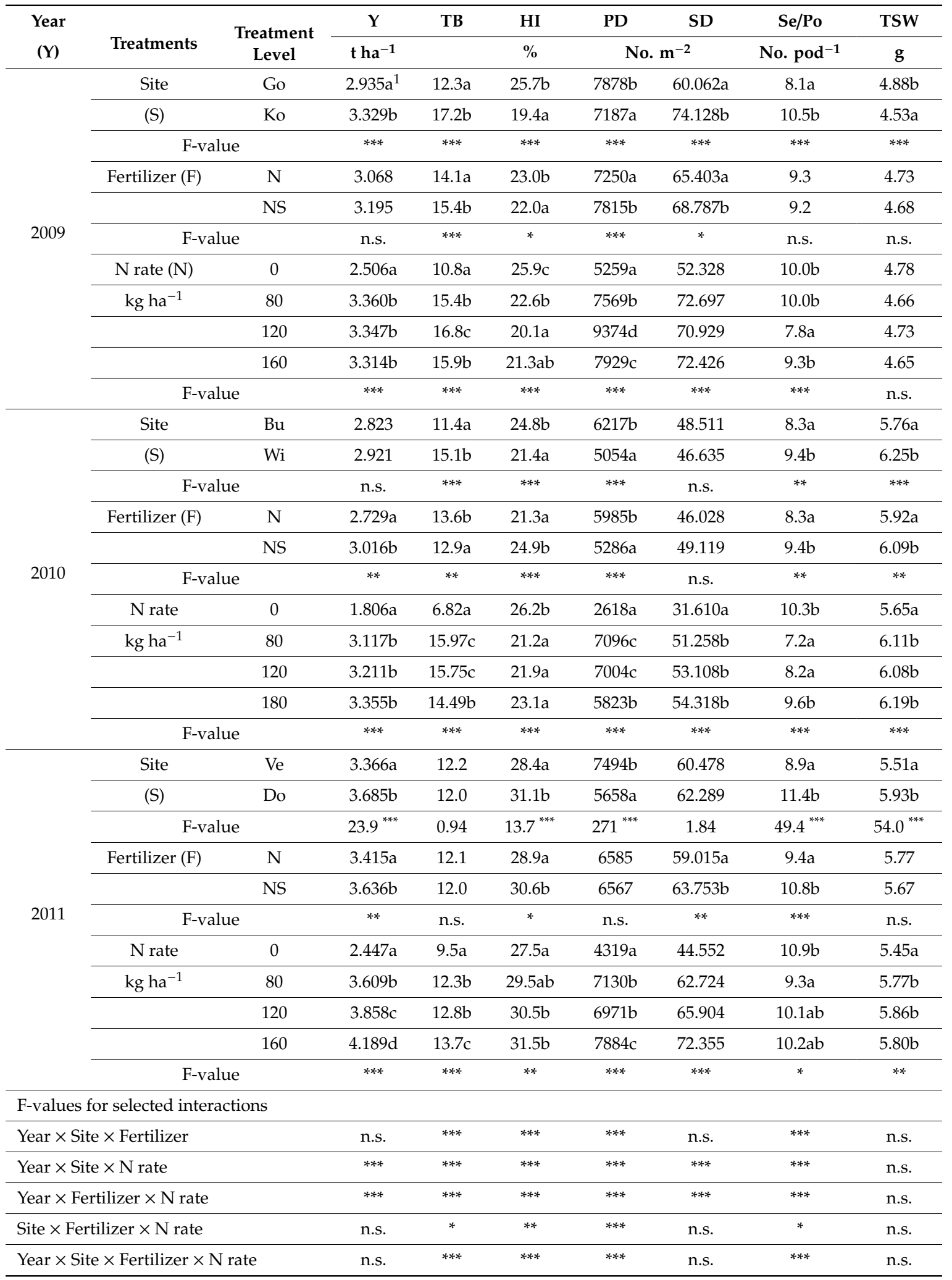

****** significant at $p<0.001 ; p<0.01 ; p<0.05$, respectively; n.s.-non significant; ${ }^{1}$ within a year, means within a column followed by the same letter indicate a lack of significant difference between the treatments. Y-yield; TB—-total biomass; HI-harvest index; PD—pod density; SD—seed density; Se/Po—number of seeds per pod;

TSW-thousand seed weight. 
The second basic yield component, i.e., TSW responded mainly to site in particular years of study. In 2009, a slightly lower TSW was the attribute of Ko, whose yield was significantly lower when compared to Go. In 2010, a significantly higher TSW was recorded for Wi, which yielded at the same level as Bu. In 2011, a significantly higher TSW for Do was in accordance with a higher yield for this site. In general, TSW showed a negative, but not significant relationship with SD, which indirectly indicates the presence of a yield compensation mechanism, which is revealed during the SFP [9].

The other yield components, i.e., pod density (PD), and the number of seeds per pod (Se/Po) exerted a much weaker impact on yield when compared to SD (Table A2). In 2009, the difference between sites with respect to the degree of PD and TSW expression were more pronounced for TSW than for PD (29.6\% vs. 9.6\%). In 2010, the opposite pattern was observed (13.3\% vs. $23 \%)$. In 2011, the yield compensation mechanisms were the highest, reaching $28 \%$ for TSW, and 38\% for PD.

\subsection{Characteristics of Nitrogen Accumulation Patterns at Harvest}

The concentration of $\mathrm{N}$ in seeds $\left(\mathrm{N}_{\mathrm{c}}\right)$ in all the study years responded mainly to site, and in 2010 and 2011, to the rate of applied $N_{f}$ (Table 4). In 2009, a significantly higher $N_{c}$ was determined in seeds for Ko than for Go. A significant, but a slightly lower difference between sites was observed in 2010 . In 2011, the average seed $N_{c}$ was the highest and the difference between fields was also very high. In 2010 and 2011, the increasing $N_{f}$ rate resulted in a progressive $N_{c}$ increase. In spite of the significant impact of site and the $\mathrm{N}_{\mathrm{f}}$ rate, the interactional impact of all experimental factors on the $\mathrm{N}_{\mathrm{c}}$ in seeds was negligible. The impact of this seed characteristic on yield was positive, but not decisive (Table A2).

The strongest impact on yield was exerted by the amount of $\mathrm{N}$ accumulated in seeds at harvest $\left(\mathrm{N}_{\mathrm{se}}\right)$ (Table A2). This WOSR characteristic responded to the interaction of $\mathrm{Y} \times \mathrm{S} \times \mathrm{N}$, and $\mathrm{Y} \times \mathrm{F} \times \mathrm{N}$. The first interaction was significantly stronger ( $p \leq 0.001$ vs. $p \leq 0.01$ ). A significant difference between sites were recorded in 2009 and 2011. In 2009, the recorded difference reached 35.1\%, but in 2011, only $20 \%$. However, both $\mathrm{N}_{\mathrm{se}}$ and yield were higher in 2011 . The effect of the $\mathrm{N}_{\mathrm{f}}$ rate was recorded in all years. As in the case of yield, $\mathrm{N}_{\mathrm{se}}$ patterns followed the same type of regression model (Table A1). The quadratic regression model, presenting a saturation level of $\mathrm{N}_{\mathrm{se}}$ accumulation, was recorded in three sites, i.e., at Go in 2009, at $\mathrm{Bu}$ in 2010, and at Do in 2011. The optimum $\mathrm{N}_{\text {fop }}$ rate for the $\mathrm{N}_{\text {semax }}$ was 92.3 for Go, 110.2 for $\mathrm{Bu}$, and $157.2 \mathrm{~kg} \mathrm{ha}^{-1}$ for Do. The respective $\mathrm{N}_{\text {semax }}$ were as $96.2,124.1$, and $154.1 \mathrm{~kg} \mathrm{ha}^{-1}$. The linear regression model, representing the unsaturation pattern of $\mathrm{N}_{\mathrm{se}}$ was recorded in the other three sites.

The amount of $\mathrm{N}$ in WOSR residues $\left(\mathrm{N}_{\text {res }}\right)$ and the nitrogen harvest index $(\mathrm{NHI})$ were highly variable between sites within a particular year. The greatest difference between studied fields was recorded in 2009, and resulted in the lowest yields. An opposite trend was recorded in 2011, when the difference between fields was much lower, reaching only 30\%, but WOSR yielded the highest. In 2009 and 2010, a significantly higher $\mathrm{N}_{\text {res }}$ was recorded for the plot fertilized with NS fertilizer. An opposite trend was recorded in 2011. In this particular year, the applied NS fertilizer resulted in a significant decrease of $\mathrm{N}_{\text {res, }}$, which corresponded to the higher seed yield. The NHI indicates the relative share of $\mathrm{N}_{\mathrm{se}}$ in the total WOSR biomass at harvest. A significant difference between sites was recorded in 2009 and 2010, but not in 2011, the year with the highest NHI. It is necessary to stress that NHI did not show any significant relationship with the $\mathrm{N}_{\mathrm{c}}$ in seeds and $\mathrm{N}_{\mathrm{se}}$, but was strongly, and negatively correlated with $\mathrm{N}_{\text {res. }}$. Finally, NHI did not impact seed yield (Table A3).

Total $\mathrm{N}$ uptake (TN) was significantly driven by all the studied factors. The effect of $\mathrm{N}$ fertilizers on TN was only significant in 2009, and 2010. The strongest response of TN to the increasing $\mathrm{N}_{\mathrm{f}}$ rate was observed in 2009, in which WOSR yielded the lowest, in spite of a very high value on the $\mathrm{N}$ control plot. TN affected yield significantly, but at a much lower level as observed for $\mathrm{N}_{\mathrm{se}}$ (Table A2). 
Table 4. Indices of nitrogen management by winter oilseed rape.

\begin{tabular}{|c|c|c|c|c|c|c|c|c|c|}
\hline \multirow{2}{*}{ Year } & \multirow{2}{*}{ Treatments } & \multirow{2}{*}{$\begin{array}{l}\text { Level of } \\
\text { Treatment }\end{array}$} & \multirow{2}{*}{$\begin{array}{c}\mathrm{N}_{\mathbf{c}} \\
\%\end{array}$} & \multirow{2}{*}{$\frac{\mathrm{N}_{\mathrm{se}}}{\mathrm{kg} \mathrm{ha}^{-1}}$} & $\mathrm{~N}_{\text {res }}$ & $\mathbf{T N}$ & \multirow{2}{*}{$\begin{array}{c}\text { NHI } \\
\%\end{array}$} & \multirow{2}{*}{$\frac{\text { UNA }}{\mathrm{kg} \mathrm{N} \mathrm{t}^{-1}}$} & \multirow{2}{*}{$\begin{array}{c}\text { UNP } \\
\mathrm{kg} \mathrm{Seeds}^{-1} \mathrm{Ng}\end{array}$} \\
\hline & & & & & \multicolumn{2}{|c|}{$\mathrm{kg} \mathrm{ha}^{-1}$} & & & \\
\hline \multirow{11}{*}{2009} & Site & Go & $2.91 \mathrm{a}^{1}$ & $85.5 a$ & $55.1 \mathrm{a}$ & $140.7 \mathrm{a}$ & $64.3 \mathrm{~b}$ & $47.4 a$ & $22.1 \mathrm{~b}$ \\
\hline & (S) & Ko & $3.47 \mathrm{~b}$ & $115.5 b$ & $113.1 \mathrm{~b}$ & $228.6 \mathrm{~b}$ & $50.6 a$ & $69.2 \mathrm{~b}$ & $14.6 \mathrm{a}$ \\
\hline & \multicolumn{2}{|c|}{ F-value } & $* * *$ & $* * *$ & $* * *$ & $* * *$ & $* * *$ & $* * *$ & $* * *$ \\
\hline & Fertilizer (F) & $\mathrm{N}$ & 3.18 & $97.9 \mathrm{a}$ & $80.4 a$ & $178.3 a$ & 57.6 & 57.4 & 18.5 \\
\hline & & NS & 3.21 & $103.2 \mathrm{~b}$ & $87.9 \mathrm{~b}$ & $191.0 \mathrm{~b}$ & 57.3 & 59.1 & 18.2 \\
\hline & \multicolumn{2}{|c|}{ F-value } & n.s. & $*$ & $*$ & $* * *$ & n.s. & n.s. & n.s. \\
\hline & $\mathrm{N}$ rate $(\mathrm{N})$ & 0 & 3.22 & $81.2 \mathrm{a}$ & $55.7 \mathrm{a}$ & $136.8 \mathrm{a}$ & $66.9 \mathrm{~b}$ & $53.9 a$ & $21.5 \mathrm{~b}$ \\
\hline & \multirow[t]{3}{*}{$\mathrm{kg} \mathrm{ha}^{-1}$} & 80 & 3.18 & $107.5 b$ & $86.9 \mathrm{~b}$ & $194.4 \mathrm{~b}$ & $56.4 a$ & $57.4 \mathrm{ab}$ & $17.9 \mathrm{a}$ \\
\hline & & 120 & 3.18 & $106.4 \mathrm{~b}$ & $93.5 \mathrm{bc}$ & $199.9 b c$ & $54.4 \mathrm{a}$ & $59.8 \mathrm{~b}$ & $17.3 \mathrm{a}$ \\
\hline & & 160 & 3.19 & $107.1 \mathrm{~b}$ & $100.5 \mathrm{c}$ & $207.5 c$ & $52.1 \mathrm{a}$ & $62.1 \mathrm{~b}$ & $16.7 \mathrm{a}$ \\
\hline & \multicolumn{2}{|c|}{ F-value } & n.s. & $* * *$ & $* * *$ & $* * *$ & $* * *$ & $* *$ & $* * *$ \\
\hline \multirow{11}{*}{2010} & Site & $\mathrm{Bu}$ & $3.49 \mathrm{~b}$ & 99.1 & $58.2 \mathrm{a}$ & $157.3 \mathrm{a}$ & $63.0 \mathrm{~b}$ & $56.2 a$ & $18.2 \mathrm{~b}$ \\
\hline & (S) & $\mathrm{Wi}$ & $3.37 \mathrm{a}$ & 99.1 & $100.6 \mathrm{~b}$ & $199.7 \mathrm{~b}$ & $50.9 \mathrm{a}$ & $68.0 \mathrm{~b}$ & $15.2 a$ \\
\hline & \multicolumn{2}{|c|}{ F-value } & $* * *$ & n.s. & $* * *$ & $* * *$ & $* * *$ & $* * *$ & $* * *$ \\
\hline & Fertilizer (F) & $\mathrm{N}$ & 3.43 & $94.6 \mathrm{a}$ & $77.1 \mathrm{a}$ & $171.8 \mathrm{a}$ & $56.0 \mathrm{a}$ & 62.4 & $16.4 a$ \\
\hline & & NS & 3.42 & $103.6 \mathrm{~b}$ & $81.7 \mathrm{~b}$ & $185.3 b$ & $57.9 \mathrm{~b}$ & 61.7 & $16.9 \mathrm{~b}$ \\
\hline & F-value & & n.s. & * & $* *$ & $* * *$ & $*$ & n.s. & $*$ \\
\hline & $\mathrm{N}$ rate $(\mathrm{N})$ & 0 & $3.25 \mathrm{a}$ & $58.5 a$ & $39.1 \mathrm{a}$ & $97.6 \mathrm{a}$ & $60.4 \mathrm{c}$ & $53.9 a$ & $18.6 \mathrm{c}$ \\
\hline & \multirow[t]{3}{*}{$\mathrm{kg} \mathrm{ha}^{-1}$} & 80 & $3.39 b$ & $105.8 \mathrm{~b}$ & $105.5 \mathrm{~d}$ & $211.3 b$ & $51.4 a$ & $70.2 \mathrm{c}$ & $15.2 \mathrm{a}$ \\
\hline & & 120 & $3.40 \mathrm{~b}$ & $109.4 \mathrm{~b}$ & $90.3 c$ & $199.8 b$ & $55.3 \mathrm{~b}$ & $63.4 \mathrm{~b}$ & $16.3 \mathrm{~b}$ \\
\hline & & 160 & $3.67 \mathrm{c}$ & $122.6 \mathrm{c}$ & $82.8 \mathrm{~b}$ & $205.4 \mathrm{~b}$ & $60.8 \mathrm{c}$ & $60.9 \mathrm{~b}$ & $16.6 \mathrm{~b}$ \\
\hline & \multicolumn{2}{|c|}{ F-value } & $* * *$ & $* * *$ & $* * *$ & $* * *$ & $* * *$ & $* * *$ & $* * *$ \\
\hline \multirow{11}{*}{2011} & Site & $\mathrm{Ve}$ & $3.29 a$ & $114.7 \mathrm{a}$ & $58.1 \mathrm{a}$ & $172.8 \mathrm{a}$ & 65.8 & $49.7 \mathrm{a}$ & $20.5 \mathrm{~b}$ \\
\hline & (S) & Do & $3.75 b$ & $137.8 \mathrm{~b}$ & $75.8 \mathrm{~b}$ & $213.6 \mathrm{~b}$ & 64.5 & $58.1 \mathrm{~b}$ & $17.4 \mathrm{a}$ \\
\hline & \multicolumn{2}{|c|}{ F-value } & $* * *$ & $* * *$ & $* * *$ & $* * *$ & n.s. & $* * *$ & $* * *$ \\
\hline & Fertilizer (F) & $\mathrm{N}$ & 3.56 & 124.1 & $70.3 \mathrm{~b}$ & 194.4 & 64.3 & $55.4 \mathrm{~b}$ & 18.5 \\
\hline & & NS & 3.48 & 128.4 & $63.6 \mathrm{a}$ & 192.0 & 65.9 & $52.4 \mathrm{a}$ & 19.5 \\
\hline & F-ve & & n.s. & n.s. & * & n.s. & n.s. & $*$ & n.s. \\
\hline & $\mathrm{N}$ rate $(\mathrm{N})$ & 0 & $3.24 \mathrm{a}$ & $84.3 \mathrm{a}$ & $49.4 \mathrm{a}$ & $133.7 \mathrm{a}$ & 64.2 & 51.1 & 20.1 \\
\hline & $\mathrm{kg} \mathrm{ha}^{-1}$ & 80 & $3.52 \mathrm{ab}$ & $128.0 \mathrm{~b}$ & $70.0 \mathrm{~b}$ & $197.9 \mathrm{~b}$ & 64.5 & 54.9 & 18.4 \\
\hline & & 120 & $3.53 \mathrm{ab}$ & $134.4 \mathrm{~b}$ & $71.3 \mathrm{~b}$ & $205.7 \mathrm{~b}$ & 64.2 & 53.2 & 19.4 \\
\hline & & 160 & $3.79 b$ & $158.3 c$ & $77.1 \mathrm{~b}$ & $235.4 \mathrm{c}$ & 67.7 & 56.5 & 18.0 \\
\hline & $\mathrm{F}-\mathrm{v}$ & & * & $* * *$ & $* * *$ & $* * *$ & n.s. & n.s. & n.s. \\
\hline F-value & r selected inter & ions & & & & & & & \\
\hline Year $\times$ & $\times$ Fertilizer & & n.s. & n.s. & $* * *$ & $* * *$ & $* * *$ & $* * *$ & $* *$ \\
\hline Year $\times$ & $\times \mathrm{N}$ rate & & n.s. & $* * *$ & $* * *$ & $* * *$ & $* * *$ & $* * *$ & $* * *$ \\
\hline Year $\times$ & tilizer $\times \mathrm{N}$ rate & & n.s. & $* *$ & $* *$ & n.s. & $* * *$ & $* *$ & n.s. \\
\hline Site $\times F$ & ilizer $\times \mathrm{N}$ rate & & n.s. & n.s. & $* * *$ & $* * *$ & $* *$ & $* * *$ & $* * *$ \\
\hline Year $\times$ & $\times$ Fertilizer $\times$ & rate & n.s. & n.s. & $* * *$ & $* * *$ & $* * *$ & $* * *$ & $* * *$ \\
\hline
\end{tabular}

$* * *, * *, *$ significant at $p<0.001 ; p<0.01 ; p<0.05$, respectively; .s. - non significant; a $^{1}$ within a year, means within a column followed by the same letter indicate a lack of significant difference between the treatments. $\mathrm{N}-\mathrm{N}$ content in seeds; $\mathrm{N}_{\mathrm{se}}, \mathrm{N}_{\mathrm{res}}$ - the amount of $\mathrm{N}$ in seeds, harvest residues, respectively; $\mathrm{TN}$-total amount of $\mathrm{N}$ in WOSR at harvest; NHI—nitrogen harvest index; UNA—unit N accumulation, UNP—unit N productivity. 
In agronomic practice, two indices are used which are reciprocal to each other, i.e., unit $\mathrm{N}$ accumulation (UNA) and unit N productivity (UNP). In spite of this, the relationship between both indices was not linear, and was expressed by the power function the best:

$$
\mathrm{UNP}=993.7 \mathrm{UNA}^{-0.996} \text { for } \mathrm{n}=24, \mathrm{R}^{2}=0.99 \text { and } p<0.001 .
$$

This type of relationship clearly shows that the unit productivity of $\mathrm{N}$ accumulated by WOSR at harvest was the highest when its accumulation was low, decreasing exponentially with its increase. Both indices responded to the interaction of all studied factors. The greatest difference for UNA, reaching $46 \%$, between sites was recorded in 2009 . This difference was slightly higher, with respect to UNP (51\%). The smallest difference was recorded in 2011 (17\%, 18\%, for UNA and UNP, respectively). The effect of $\mathrm{N}_{\mathrm{f}}$ type was, in general, low, being in most cases not significant. The effect of the increasing $\mathrm{N}_{\mathrm{f}}$ rate was site specific. The most conspicuous impact of UNA was recorded for TN and HI. The first WOSR characteristic responded positively, but the second negatively to UNA increase (Table A2).

The applied principal component analysis (PCA) clearly revealed the distinct impact of yield components and crop $\mathrm{N}$ indices on the WOSR final yield. PCs with eigenvalues greater than 1.0 were used as a primary criterion to determine the number of PCs. The first four PCs accounted for $92.27 \%$ of the total variance in the data (Table A3). However, only the variables with scores on PCs over 0.70 $\left(\mathrm{R}^{2}>0.50\right)$ were taken into consideration. PC1 and PC2 contributed to $49.43 \%$ and $22.12 \%$ of the total variance, respectively. Four of the nine variables had high loadings on PC1, fulfilling the chosen criteria. The highest, and at the same time positive loadings, were recorded in descending order $(r)$ for $\mathrm{Y}=\mathrm{N}_{\mathrm{se}}=\mathrm{TN}>\mathrm{SD}$. The required criteria for PC2 were reached for PD, and for PC3 for Se/Po (negative). PC4 had a positive loading for UNA. The studied variable weight was evaluated by the Eigen vector, which varies between -1 to +1 . The Eigen vectors for the examined variables were broadly scattered on the two first PCA axes (Figure 1a). The closest to an absolute of 1 were TN, $\mathrm{N}_{\mathrm{se}}$, and $\mathrm{Y}$. The distance of $N_{\text {se }}$ to $Y$, as seen from Figure $1 b$, was the closest among the studied $N$ indices and yield components. The $\mathrm{N}_{\mathrm{c}}$ in seeds exerted the same loading on both PC1 and PC2 axes (Table A3).

\subsection{Indices of Fertilizer $N$ Management}

The partial factor productivity of fertilizer $\mathrm{N}\left(\mathrm{PFP}_{\mathrm{N}}\right)$ is the basic index, describing the productivity of applied $\mathrm{N}_{\mathrm{f}}$ [29]. In the studied case, $\mathrm{PFP}_{\mathrm{N}}$ was significantly driven by $\mathrm{Y} \times \mathrm{S} \times \mathrm{N}$, and $\mathrm{Y} \times \mathrm{F} \times \mathrm{N}$ interactions (Table 5). The $\mathrm{PFP}_{\mathrm{N}}$ indices in 2011 were the highest, and the difference between sites was small (5.3\%). The lowest $\mathrm{PFP}_{\mathrm{N}}$ indices, but at the same time, the highest difference between sites, were recorded in 2009 and $2010(13 \%)$. The $\mathrm{PFP}_{\mathrm{N}}$ decreased in accordance with the progressively increasing $\mathrm{N}_{\mathrm{f}}$ rate, irrespective of other factors.

The next index, i.e., agronomic efficiency of $\mathrm{N}_{\mathrm{f}}\left(\mathrm{AE}_{\mathrm{N}}\right)$ was driven by the same set of factors as $\mathrm{PFP}_{\mathrm{N}}$. A significant, and at the same time, a very strong difference between fields was recorded in 2010 and 2011 , reaching $137 \%$ and $81 \%$, respectively. The effect of the type of $\mathrm{N}$ fertilizer was significant in all of the studied years, clearly indicating a significantly higher $\mathrm{N}$ net productivity in the presence of sulfur. The highest $\mathrm{AE}_{\mathrm{N}}$ increase in response to the $\mathrm{NS}$ fertilizer was recorded in 2011, a year with the highest yields. The lowest drop in $\mathrm{AE}_{\mathrm{N}}$ in response to the increasing $\mathrm{N}$ rates was also recorded in 2011. It was twice as low as recorded in 2010, when it was the highest. 
Table 5. Indices of nitrogen management by WOSR.

\begin{tabular}{|c|c|c|c|c|c|c|}
\hline Year & Treatments & Level of Treatment & $\mathbf{P F P}_{\mathbf{N}}$ & $\begin{array}{c}\mathrm{AE}_{\mathrm{N}} \\
\mathrm{kg} \mathrm{kg}^{-1}\end{array}$ & $\mathrm{PE}_{\mathrm{N}}$ & $\begin{array}{c}\mathbf{R}_{\mathrm{N}} \\
\%\end{array}$ \\
\hline \multirow{10}{*}{2009} & Site & Go & $28.3 a^{1}$ & 7.3 & $6.3 b$ & $72.6 b$ \\
\hline & (S) & Ko & $32.1 b$ & 8.3 & $3.5 a$ & $39.8 \mathrm{a}$ \\
\hline & F-value & & $* * *$ & n.s. & $* * *$ & $* * *$ \\
\hline & Fertilizer & $\mathrm{N}$ & $29.4 \mathrm{a}$ & $7.0 \mathrm{a}$ & $3.2 \mathrm{a}$ & $46.4 \mathrm{a}$ \\
\hline & $(\mathrm{F})$ & NS & $31.0 \mathrm{~b}$ & $8.6 \mathrm{~b}$ & $6.5 b$ & $66.0 \mathrm{~b}$ \\
\hline & F-value & & * & * & ** & $* * *$ \\
\hline & $\mathrm{N}$ rate & 80 & $42.0 \mathrm{c}$ & $11.0 \mathrm{~b}$ & $8.5 b$ & $71.9 \mathrm{~b}$ \\
\hline & $(\mathrm{N})$ & 120 & $27.9 \mathrm{ab}$ & $7.2 \mathrm{a}$ & $3.9 a$ & $52.5 a$ \\
\hline & $\mathrm{kg} \mathrm{ha}^{-1}$ & 160 & 20.7 & $5.2 \mathrm{a}$ & $2.3 \mathrm{a}$ & $44.2 \mathrm{a}$ \\
\hline & \multicolumn{2}{|c|}{ F-value } & $* * *$ & $* * *$ & $* * *$ & $* * *$ \\
\hline \multirow{10}{*}{2010} & Site & $\mathrm{Bu}$ & $30.8 b$ & $18.0 \mathrm{~b}$ & $21.8 b$ & $103.9 b$ \\
\hline & $(\mathrm{S})$ & Wi & $27.5 \mathrm{a}$ & $7.6 \mathrm{a}$ & $7.5 a$ & $94.2 \mathrm{a}$ \\
\hline & F-value & & $* *$ & $* * *$ & $* * *$ & * \\
\hline & Fertilizer & $\mathrm{N}$ & $27.6 a$ & $11.3 \mathrm{a}$ & 13.2 & $90.9 a$ \\
\hline & $(\mathrm{F})$ & NS & $30.6 b$ & $14.3 \mathrm{~b}$ & 16.2 & $107.2 b$ \\
\hline & F-value & & $* *$ & $* *$ & n.s. & $* * *$ \\
\hline & $\mathrm{N}$ rate & 80 & $39.7 \mathrm{c}$ & $17.1 \mathrm{~b}$ & $25.6 \mathrm{~b}$ & $144.6 \mathrm{c}$ \\
\hline & $(\mathrm{N})$ & 120 & $26.8 \mathrm{~b}$ & $11.7 \mathrm{a}$ & $11.7 \mathrm{a}$ & $85.1 b$ \\
\hline & $\mathrm{kg} \mathrm{ha}^{-1}$ & 160 & $21.0 \mathrm{a}$ & $9.7 a$ & $6.7 a$ & $67.4 a$ \\
\hline & \multicolumn{2}{|c|}{ F-value } & $* * *$ & $* * *$ & $* * *$ & $* * *$ \\
\hline \multirow{10}{*}{2011} & Site & Ve & $33.6 a$ & $15.9 \mathrm{~b}$ & $13.1 \mathrm{~b}$ & $79.2 \mathrm{~b}$ \\
\hline & (S) & Do & $35.4 \mathrm{~b}$ & $8.8 \mathrm{a}$ & $5.2 \mathrm{a}$ & $50.0 \mathrm{a}$ \\
\hline & F-value & & * & $* * *$ & $* * *$ & $* * *$ \\
\hline & Fertilizer & $\mathrm{N}$ & $32.7 \mathrm{a}$ & $10.6 a$ & $7.2 \mathrm{a}$ & 61.9 \\
\hline & $(\mathrm{F})$ & NS & $36.2 b$ & $14.2 \mathrm{~b}$ & $11.2 \mathrm{~b}$ & 67.3 \\
\hline & F-value & & $* * *$ & $* * *$ & $* * *$ & n.s. \\
\hline & $\mathrm{N}$ rate & 80 & $45.1 \mathrm{c}$ & $14.5 b$ & $12.7 \mathrm{~b}$ & 75.7 \\
\hline & $(\mathrm{N})$ & 120 & $32.2 \mathrm{~b}$ & $11.8 \mathrm{a}$ & $7.2 \mathrm{a}$ & 56.9 \\
\hline & $\mathrm{kg} \mathrm{ha}^{-1}$ & 160 & $26.2 \mathrm{a}$ & $10.9 a$ & $7.7 \mathrm{a}$ & 61.2 \\
\hline & & -value & $* * *$ & $* * *$ & $* * *$ & n.s. \\
\hline
\end{tabular}

F-value for selected interactions

\begin{tabular}{lcccc} 
Year $\times$ Site $\times$ Fertilizer & n.s. & n.s. & n.s. & $* * *$ \\
\hline Year $\times$ Site $\times$ N rate & $* * *$ & $* * *$ & $* * *$ & $* * *$ \\
\hline Year $\times$ Fertilizer $\times$ N rate & $* * *$ & $* * * *$ & $* * * *$ & n.s. \\
\hline Site $\times$ Fertilizer $\times$ N rate & n.s & n.s & n.s & $* *$ \\
\hline Year $\times$ Site $\times$ Fertilizer $\times$ N rate & n.s & n.s & n.s & $* *$ \\
\hline
\end{tabular}

$* * *, * *, *$ significant at $p<0.001 ; p<0.01 ; p<0.05$, respectively; n.s.- -non significant; $\mathrm{a}^{1}$ within a year, means within a column followed by the same letter indicate a lack of significant difference between the treatments. $\mathrm{PFP}_{\mathrm{N}}-$ partial factor productivity of fertilizer $\mathrm{N} ; \mathrm{AE}_{\mathrm{N}}$ agronomic efficiency of fertilizer $\mathrm{N} ; \mathrm{PE}_{\mathrm{N}}$-physiological efficiency of fertilizer $\mathrm{N}$; recovery of fertilizer $\mathrm{N}$. 
The physiological $\mathrm{N}$ use efficiency index $\left(\mathrm{PE}_{\mathrm{N}}\right)$, describing the utilization efficiency of $\mathrm{N}$ taken up by a plant during the growing season, significantly responded to the same set of factors as described for $\mathrm{AE}_{\mathrm{N}}$. Each year, the differences between sites were extremely high. In 2009, a net productivity of $1.0 \mathrm{~kg}$ of $\mathrm{N}$ taken up by WOSR plants was $80 \%$ higher in the field located at Go, as compared to Ko. In 2010, the observed difference between sites was twice as high. In 2011, the difference between sites was much smaller, but also high, amounting to $152 \%$. The effect of NS fertilizer was as a rule positive, and a significant response to $S$ was observed in 2009 and 2011. The effect of the increasing $\mathrm{N}_{\mathrm{f}}$ rate on $\mathrm{PE}_{\mathrm{N}}$ was clearly demonstrated in 2009 and 2010, decreasing in accordance with the increased $\mathrm{N}_{\mathrm{f}}$ rate. In 2011, index stagnation in plots fertilized with $\mathrm{N}$ at the rate of 120 and $160 \mathrm{~kg} \mathrm{ha}^{-1}$ was recorded.

Nitrogen recovery $\left(R_{N}\right)$ reveals the contribution of $N$ fertilizer in the total $N$ taken by a crop during the growing season. $R_{N}$ indices responded significantly to all the studied factors, including years. The highest $R_{N}$ values were recorded in 2010, exceeding $100 \%$ in the field located at $\mathrm{Bu}(105 \%)$. In this particular year, the difference between sites was low (9.7\%). The lowest $R_{N}$ of $39.8 \%$ was recorded in 2009 at Ko, being, however, twice as high at Go. The same trend was recorded in 2010, but the difference between sites was $29.2 \%$. The effect of NS fertilizer on $R_{N}$ was as a rule positive, but not significant in 2009. A positive impact of NS on $R_{N}$ was noted in 2009 at Ko; in 2010 at Wi, and in 2011 at Ve. The effect of the increasing $\mathrm{N}_{\mathrm{f}}$ rate on $\mathrm{R}_{\mathrm{N}}$ showed the same pattern, as presented for the other $\mathrm{N}$ indices. In 2010, it exceeded $100 \%$ on plots fertilized with $\mathrm{N}_{\mathrm{f}}$ at the rate of $80 \mathrm{~kg} \mathrm{ha}^{-1}$.
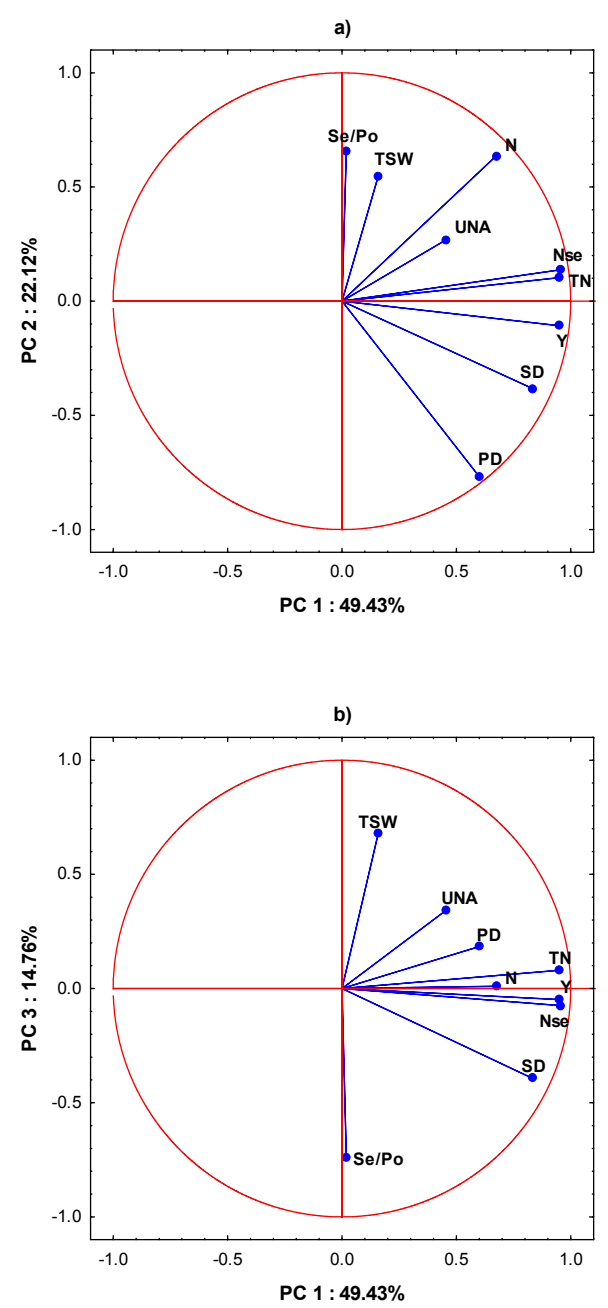

Figure 1. Score plot of WOSR components and nitrogen indices in PC1 and PC2 axes (a) and PC1 and PC3 axes (b). Y—yield, SD—seed density, PD—pod density, TSW—thousand seed weight, TN—total nitrogen, $\mathrm{N}_{\mathrm{c}}-\mathrm{N}$ concentration in seeds, $\mathrm{N}_{\mathrm{se}}-\mathrm{N}$ accumulated in seeds, UNA-unit $\mathrm{N}$ accumulation. 


\subsection{Indices of Soil N Management}

Nitrogen input $\left(\mathrm{N}_{\mathrm{in}}\right)$ is composed of two $\mathrm{N}$ mineral sources. The first, internal (indigenous) source, is soil mineral $\mathrm{N}$ measured in spring $\left(\mathrm{N}_{\text {mins }}\right)$, which is recorded in the soil at the onset of WOSR spring regrowth. The second one is the amount of $\mathrm{N}_{\mathrm{f}}$ applied to the growing crop during spring vegetation [23]. In the studied case, the $\mathrm{N}_{\mathrm{f}}$ rate was 80,120 , and $160 \mathrm{~kg} \mathrm{ha}^{-1}$ (Table 6). Due to a fixed amount of applied $\mathrm{N}_{\mathrm{f}}$, it was not possible to evaluate $\mathrm{N}_{\text {in }}$ statistically. In spite of this, the difference between sites was the most pronounced in 2011 (90\%), followed by 2009 (33\%), and the least pronounced in 2010 (12\%).

The residual $\mathrm{N}\left(\mathrm{N}_{\operatorname{minr}}\right)$ is the amount of $\mathrm{N}_{\min }$ measured just after WOSR harvest. This $\mathrm{N}$ characteristic showed a significant impact of all studied factors. As in the case of yield, $\mathrm{N}_{\operatorname{minr}}$ was evaluated based on the $\mathrm{Y} \times \mathrm{S} \times \mathrm{N}$ interaction. The difference between sites was evaluated based on two indices, referring to the $\mathrm{N}_{\text {minr }}$ content on the $\mathrm{N}$ control plot and to its maximum value, as an indicator of the applied rate of $\mathrm{N}_{\mathrm{f}}$ :

1. The Nminr content on the $\mathrm{N}$ control plot:

$$
\text { a. } \quad \text { Go }(52.0)<\operatorname{Do}\left(83.5<\mathrm{Bu}(98.3) \leq \mathrm{Ko}(102.5)<\mathrm{Wi}(117.2)<\mathrm{Ve}\left(146.1 \mathrm{~kg} \mathrm{ha}^{-1}\right) .\right.
$$

2. The maximum $\mathrm{N}_{\operatorname{minr}}$ content:

$$
\text { b. } \quad \text { Go }(85.6)<\mathrm{Ko}(102.5)<\mathrm{Bu}(111.8) \leq \mathrm{Wi}(119.5) \leq \mathrm{Do}(121.1)<\mathrm{Ve}\left(146.1 \mathrm{~kg} \mathrm{ha}^{-1}\right) \text {. }
$$

3. The net $\mathrm{N}_{\text {minr }}$ increase with respect to the $\mathrm{N}$ control:

$$
\text { c. } \quad \mathrm{Do}(+37.6)>\mathrm{Go}(+33.5)>\mathrm{Ko}(+18.6)>\mathrm{Bu}(+13.5)>\mathrm{Wi}(+2.3)>\mathrm{Ve}\left(+0.0 \mathrm{~kg} \mathrm{ha}^{-1}\right)
$$

The highest amount of residual $\mathrm{N}_{\min }$ was recorded, irrespective of the applied $\mathrm{N}_{\mathrm{f}}$ rate, at Ve. The lack of differences between the control $\mathrm{N}$ plot and the $\mathrm{N}_{\mathrm{f}}$ highest rate indicates that $\mathrm{N}$ was taken up by WOSR plants with the same efficiency. For other fields, the net effect of $\mathrm{N}_{\mathrm{f}}$ was highly diversified between years and sites. The difference between sites in 2011 was very strong $(47 \%)$. In the case of Do, the $\mathrm{N}_{\operatorname{minr}}$ content increased progressively with the increased $\mathrm{N}_{\mathrm{f}}$ rate. The lowest amount of $\mathrm{N}_{\operatorname{minr}}$ was recorded in 2009 and the difference between sites was significant (27\%). In the case of Go, the amount of $\mathrm{N}_{\text {minr }}$ increased linearly with the applied $\mathrm{N}_{\mathrm{f}}$ rate.

Nitrogen balance $\left(\mathrm{N}_{\mathrm{b}}\right)$ was significantly driven by all factors in the study. A positive $\mathrm{N}_{b}$ value indicates the presence of a sufficiently high pool of $\mathrm{N}_{\text {min }}$ present in spring. A negative $\mathrm{N}_{b}$ value indicates $\mathrm{N}_{\min }$ net release from soil resources during the growing season. The differences between sites in particular years were extremely high. A positive $\mathrm{N}_{b}$ was registered in two sites, i.e., in 2009 for Go, and in 2011 for Ve. In the other four sites, a high release of $\mathrm{N}_{\min }$ from soil resources during the growing season was recorded. In the first two years, $\mathrm{N}_{\mathrm{b}}$ was negative, irrespective of the type of applied $\mathrm{N}$ fertilizer. A quite opposite trend was revealed in 2011. The effect of increasing $\mathrm{N}_{\mathrm{f}}$ rates was year specific. In 2009, negative $\mathrm{N}_{\mathrm{b}}$ values were recorded on plots with low $\mathrm{N}$ rates (up to $80 \mathrm{~kg} \mathrm{ha}^{-1}$ ). In 2010, the observed trend was opposite. In 2011, $\mathrm{N}_{\mathrm{b}}$ decreased with the $\mathrm{N}_{\mathrm{f}}$ rate increase.

The next characteristic of $\mathrm{N}$ management during the growing season is $\mathrm{N}_{\text {gain, }}$, i.e., the net amount of $\mathrm{N}$ taken up by a crop from soil $\mathrm{N}$ resources during the growing season. Its variability was most affected by the interactional effect of $Y \times S \times N$. The impact of years was tremendous. In $2009, \mathrm{~N}_{\text {gain }}$ was positive, and the difference between fields was 10-fold. In 2010, $\mathrm{N}_{\text {gain }}$ was extremely high, and the difference between sites was high, but much smaller when compared to 2009. A 4-fold difference between sites was observed in 2011. The effect of $N$ fertilizer type appeared only in 2009 when the application of NS fertilizer increased the net amount of $\mathrm{N}_{\min }$ by $19 \%$. The effect of increasing $\mathrm{N}$ rates on $\mathrm{N}_{\text {gain }}$ followed two patterns (Table $\mathrm{A} 4$ ), linear (Ko, Ve, Do), and quadratic (Go, Bu, Wi). 
Table 6. Indices of nitrogen management in the soil/plant system.

\begin{tabular}{|c|c|c|c|c|c|c|c|}
\hline Year & Treatments & Level of Treatments & $\mathbf{N}_{\text {in }}$ & $\mathbf{N}_{\operatorname{minr}}$ & $\underset{\text { kg ha }^{-1}}{N_{b}}$ & $\mathbf{N}_{\text {gain }}$ & $\mathbf{N}_{\text {int }}$ \\
\hline \multirow{11}{*}{2009} & Site & Go & 199.2 & $74.1 \mathrm{a}^{1}$ & $56.6 \mathrm{~b}$ & $17.5 \mathrm{a}$ & $216.7 a$ \\
\hline & (S) & Ko & 149.7 & $94.4 \mathrm{~b}$ & $-78.9 \mathrm{a}$ & $173.3 \mathrm{~b}$ & $323.0 \mathrm{~b}$ \\
\hline & F-value & & n.a. & $* * *$ & $* * *$ & $* * *$ & $* * *$ \\
\hline & Fertilizer (F) & $\mathrm{N}$ & 174.5 & 82.3 & $-4.8 \mathrm{~b}$ & $87.1 \mathrm{a}$ & $261.5 a$ \\
\hline & & NS & 174.5 & 86.2 & $-17.5 \mathrm{a}$ & $103.7 \mathrm{~b}$ & $278.2 \mathrm{~b}$ \\
\hline & \multicolumn{2}{|c|}{ F-value } & n.a. & n.s. & $* * *$ & $* * *$ & $* * *$ \\
\hline & $\mathrm{N}$ rate $(\mathrm{N})$ & 0 & 84.5 & $77.3 a$ & $-56.1 \mathrm{a}$ & $133.4 \mathrm{~d}$ & $217.9 a$ \\
\hline & & 80 & 164.5 & $80.0 \mathrm{a}$ & $-29.9 \mathrm{~b}$ & $109.9 \mathrm{c}$ & $274.3 \mathrm{~b}$ \\
\hline & & 120 & 204.5 & $87.8 \mathrm{ab}$ & $4.6 \mathrm{c}$ & $83.3 \mathrm{~b}$ & $287.7 \mathrm{bc}$ \\
\hline & & 180 & 244.5 & $92.0 \mathrm{~b}$ & $36.9 \mathrm{~d}$ & $55.1 \mathrm{a}$ & $299.5 c$ \\
\hline & & value & n.a. & $* *$ & $* * *$ & $* * *$ & $* * *$ \\
\hline \multirow{11}{*}{2010} & Site & $\mathrm{Bu}$ & 156.0 & $104.9 \mathrm{a}$ & $-1.3 b$ & $106.2 \mathrm{a}$ & $262.2 \mathrm{a}$ \\
\hline & (S) & $\mathrm{Wi}$ & 139.0 & $115.6 \mathrm{~b}$ & $-60.7 a$ & $176.3 b$ & $315.3 b$ \\
\hline & F-value & & n.a. & ** & $* * *$ & $* * *$ & $* * *$ \\
\hline & Fertilizer (F) & $\mathrm{N}$ & 147.5 & $116.8 \mathrm{~b}$ & -24.3 & 141.1 & 288.6 \\
\hline & & NS & 147.5 & $103.6 \mathrm{a}$ & -37.8 & 141.3 & 288.8 \\
\hline & \multicolumn{2}{|c|}{ F-value } & n.a. & $* * *$ & n.s. & n.s. & n.s. \\
\hline & $\mathrm{N}$ rate $(\mathrm{N})$ & 0 & 147.5 & $104.0 \mathrm{a}$ & $49.9 \mathrm{~b}$ & $54.1 \mathrm{a}$ & $201.6 a$ \\
\hline & & 80 & 147.5 & $113.4 \mathrm{ab}$ & $-63.8 \mathrm{a}$ & $177.2 \mathrm{~b}$ & $324.7 \mathrm{~b}$ \\
\hline & & 120 & 147.5 & $117.1 \mathrm{~b}$ & $-52.3 a$ & $169.4 \mathrm{~b}$ & $316.9 \mathrm{ab}$ \\
\hline & & 180 & 147.5 & 106.4ab & $-57.9 \mathrm{a}$ & $164.2 \mathrm{~b}$ & $311.7 \mathrm{ab}$ \\
\hline & & value & n.a. & $*$ & $* * *$ & $* * *$ & $* * *$ \\
\hline \multirow{11}{*}{2011} & Site & $\mathrm{Ve}$ & 275.0 & $147.2 \mathrm{~b}$ & $102.2 b$ & $45.0 \mathrm{a}$ & 320.0 \\
\hline & (S) & Do & 145.0 & $100.4 a$ & $-68.6 a$ & $169.0 \mathrm{~b}$ & 314.0 \\
\hline & F-value & & n.a. & $* * *$ & $* * *$ & $* * *$ & n.s. \\
\hline & Fertilizer $(\mathrm{F})$ & $\mathrm{N}$ & 210.0 & 122.2 & 15.6 & 106.6 & 316.6 \\
\hline & & NS & 210.0 & 125.4 & 18.0 & 107.4 & 317.4 \\
\hline & \multicolumn{2}{|c|}{ F-value } & n.a. & n.s. & n.s. & n.s. & n.s. \\
\hline & \multirow[t]{5}{*}{$\mathrm{N}$ rate $(\mathrm{N})$} & 0 & 210.0 & $114.8 \mathrm{ab}$ & $76.3 b$ & $38.5 a$ & $248.5 a$ \\
\hline & & 80 & 210.0 & $113.1 \mathrm{a}$ & $12.1 \mathrm{ab}$ & $101.0 \mathrm{ab}$ & $311.0 \mathrm{~b}$ \\
\hline & & 120 & 210.0 & $133.2 \mathrm{ab}$ & $4.3 \mathrm{a}$ & $128.9 \mathrm{~b}$ & $338.9 \mathrm{c}$ \\
\hline & & 180 & 210.0 & $134.1 \mathrm{~b}$ & $-25.4 a$ & $159.5 b$ & $369.5 \mathrm{~d}$ \\
\hline & & value & n.a. & $* *$ & $* *$ & $* *$ & $* * *$ \\
\hline \multicolumn{8}{|c|}{ F-values for selected interactions } \\
\hline \multicolumn{3}{|c|}{ Year $\times$ Site $\times$ Fertilizer } & n.a. & $* * *$ & $* * *$ & n.s. & n.s. \\
\hline \multicolumn{3}{|c|}{ Year $\times$ Site $\times N$ rate } & n.a. & *** & $* * *$ & $* * *$ & $* * *$ \\
\hline \multicolumn{3}{|c|}{ Year $\times$ Fertilizer $\times N$ rate } & n.a. & ** & n.e. & $* *$ & $* *$ \\
\hline \multicolumn{3}{|c|}{ Site $\times$ Fertilizer $\times N$ rate } & n.a. & ** & $* * *$ & $* *$ & $* *$ \\
\hline \multicolumn{3}{|c|}{ Year $\times$ Site $\times$ Fertilizer $\times N$ rate } & n.a. & n.s. & $* * *$ & * & * \\
\hline
\end{tabular}

***,***${ }^{*}$ significant at $p<0.001 ; p<0.01 ; p<0.05$, respectively; n.s.- non significant; n.a.- -non analyzed. a ${ }^{1}$ within a year, means within a column followed by the same letter indicate a lack of significant difference between the treatments. $\mathrm{N}_{\text {in }}$-indigenous $\mathrm{N}\left(\mathrm{N}_{\mathrm{i}}\right)+$ fertilizer $\mathrm{N}\left(\mathrm{N}_{\mathrm{f}}\right)$; $\mathrm{N}_{\operatorname{minr}}$-residual $\mathrm{N}_{\min }$ (post-harvest $\mathrm{N}_{\min }$ ); $\mathrm{N}_{\mathrm{b}}-\mathrm{N}$ balance; $\mathrm{N}_{\text {gain }}-\mathrm{N}$ mineralized during the growing season and incorporated into WOSR biomass; $\mathrm{N}_{\text {int }}$-total $\mathrm{N}$ input into the soil/plant system during the growing season. 
Total $\mathrm{N}$ input $\left(\mathrm{N}_{\mathrm{int}}\right)$ responded almost to the same set of factors and their interactions as recorded for $\mathrm{N}_{\text {gain. }}$. A significant impact of site was recorded in 2009 and 2010 but not in 2011, during which WOSR yielded the highest. The effect of $\mathrm{N}$ fertilizer type was the same as observed for $\mathrm{N}_{\text {gain }}$. The effect of $\mathrm{N}$ rates was year specific. The effect of increasing $\mathrm{N}$ rates on $\mathrm{N}_{\text {int }}$ followed two patterns linear (Ko, Ve, Do), and quadratic (Go, Bu, Wi), i.e., showing a high resemblance to $\mathrm{N}_{\text {gain }}$ patterns (Table A4).

\section{Discussion}

The yield of any crop, including WOSR, is highly variable, being affected by three key factors: (i) the course of weather during the growing season, (ii) soil fertility level, and (iii) N supply to plants during the critical periods of formation of yield components $[22,30]$. Four criteria were chosen for the evaluation of year-site differences in yield:

1. Seed density (SD);

2. Amount of $\mathrm{N}$ in seeds $\left(\mathrm{N}_{\mathrm{se}}\right)$;

3. N sources: indigenous $\mathrm{N}$ in spring, fertilizer $\mathrm{N}$, in-season $\mathrm{N}\left(\mathrm{N}_{\text {in }}, \mathrm{N}_{\text {int }}\right)$;

4. $\mathrm{N}$ productivity $\left(\mathrm{PFPN}_{\text {in }}, \mathrm{PFPN}_{\text {int }}\right)$.

\subsection{Seed Density and Yield}

The basis of a soil productivity evaluation in a field experiment is the yield obtained on a plot without application of fertilizer nitrogen $\left(\mathrm{N}_{\mathrm{f}}\right)$, i.e., $\mathrm{N}$ control plot. A crop response to the applied $\mathrm{N}_{\mathrm{f}}$ indicates its potential productivity, assuming an optimization of $\mathrm{N}$ supply [15,30]. The study clearly showed that the natural, indigenous productivity of the studied sites, with respect to its content in spring $\left(\mathrm{N}_{\text {mins }}\right)$, differed significantly. The order of sites, assuming a $10 \%$ difference between sites $\left[\left(S_{n}-S_{n-1}\right) / S_{n}<0.1\right]$, as the discrimination criterion was as follows:

$$
\operatorname{Do}(2.93) \geq \operatorname{Ko}(2.65)>\operatorname{Go}(2.28) \geq \operatorname{Wi}(2.10) \geq \operatorname{Ve}(2.01)>\mathrm{Bu}\left(1.41 \mathrm{tha}^{-1}\right)
$$

The order obtained clearly indicates that the fields located at Do and Ko were, irrespective of year, the most productive. On both these sites, the indigenous $\mathrm{N}$ content in spring was low compared to the other sites, but the content of available $\mathrm{K}$ and $\mathrm{Mg}$ was high, consequently creating favorable conditions for enhancing $\mathrm{N}$ productivity, as corroborated by high values of the $\mathrm{PFP}_{\mathrm{N}}$ index (Tables 2 and 5). It has been recently documented that a shortage of these nutrients disturbs the development of yield components during both the onset of flowering and SFP [11,25,31,32]. The second group of studied sites, showing a relatively high $\mathrm{N}_{\mathrm{i}}$ productivity, comprised three sites, i.e., Go (2009), Wi (2010), and Ve (2011). The main reason for the high yield was the high content of $\mathrm{N}_{\text {mins }}$ at Go and Ve, which exceeded $100 \mathrm{~kg} \mathrm{ha}^{-1}$ (Table 1). The fertility level of soil at $\mathrm{Wi}$, including $\mathrm{N}_{\text {mins }}$ content, was only moderate. The third group, with the lowest yield, comprised only one site, i.e., $\mathrm{Bu}$ (2010).

A different order of sites was obtained based on the $\mathrm{N}_{\mathrm{f}}$ optimum $\left(\mathrm{N}_{\text {fop }}\right)$ or $\mathrm{N}_{\mathrm{fmax}}$, taking into account the mode of yield response to the applied $\mathrm{N}_{\mathrm{f}}$, i.e., quadratic and linear, respectively:

1. $\operatorname{Ve}(4.46)>\operatorname{Do}(4.01) \geq \mathrm{Wi}(3.79) \geq \mathrm{Ko}(3.63)=\mathrm{Bu}(3.59)>\mathrm{Go}\left(3.14 \mathrm{t} \mathrm{ha}^{-1}\right)$;

2. Yield increase: $\mathrm{Ve}(+2.45)>\mathrm{Bu}(+2.18)>\mathrm{Wi}(+1.69)>\mathrm{Go}(+1.38)>\mathrm{Do}(+1.08) \geq \mathrm{Ko}(+0.98)$.

The highest yield was harvested at Ve, where it increased linearly in relation to the applied $\mathrm{N}_{\mathrm{f}}$. The same type of response was found for Wi, but at a much lower level. This type of WOSR response to $\mathrm{N}_{\mathrm{f}}$ indicates that the $\mathrm{N}_{\mathrm{f}}$ rate of $160 \mathrm{~kg} \mathrm{ha}^{-1}$ was too low to maximize crop productivity in these two sites. A limited supply of $\mathrm{N}$ to WOSR plants during pre-flowering growth results in a significant decrease in PD and SD, i.e., yield components determining the sink strength [11,33]. A slightly lower yield response to $\mathrm{N}_{\mathrm{f}}$, as compared to $\mathrm{Ve}$, was recorded for $\mathrm{Bu}$. In this site, a $\mathrm{N}_{\mathrm{f}}$ of $104.3 \mathrm{~kg}^{-1}$ was sufficient to reach the maximum yield. The same type of response was the attribute of the other three sites, located at Go, Do, and Ko. The quadratic response model of $\mathrm{N}_{\mathrm{f}}$ impact on WOSR yield indicates 
the occurrence of factors constraining $\mathrm{N}_{\mathrm{f}}$ productivity. In this case, the most probable reason for the limited $\mathrm{N}_{\mathrm{f}}$ productivity was the shortage of nutrients other than $\mathrm{N}$ during SFP, which are responsible for the supply of assimilates to the growing pods and seeds [34,35].

Yield of WOSR was significantly driven by SD. The course of weather in a particular growing season was revealed as a decisive factor, impacting the course of the obtained trends. As shown in Figure 2, WOSR yield in 2009 fitted the quadratic regression model the best, indicating a saturation status of SD. In this exact year, an SD of $90.2 \mathrm{~m}^{-2}$ resulted in the $Y_{\max }$ of $3.661 \mathrm{t} \mathrm{ha}^{-1}$. In the other two years, irrespective of the site, yield increased linearly with the increased SD. The impact of the N pools on SD was analyzed based on the effect of:

(1) Indigenous $\mathrm{N}\left(\mathrm{N}_{\text {mins }}\right.$, control $\mathrm{N}$ plot $)$ :

$$
\text { Ko }(57707)>\text { Do }(49646) \geq \text { Go }(49562)>\text { Ve }(39935)>\text { Wi }(34135)>\text { Bu }\left(27745 \text { seeds m }{ }^{-2}\right) \text {. }
$$

(2) $\mathrm{N}$ input $\left(\mathrm{N}_{\text {in }}\right)$ for $\mathrm{N}_{\text {fop }}$ or $\mathrm{N}_{\text {fmax }}$ for respective treatments:

$$
\text { Ko }(83612) \geq \operatorname{Ve}(76463)>\text { Do }(67810) \geq \text { Go }(66312) \geq \text { Bu (59755) } \geq \text { Wi }\left(56359 \text { seeds }^{-2}\right) \text {. }
$$

The net $\mathrm{SD}$ increase in response to $\mathrm{N}_{\text {fop }}$ or $\mathrm{N}_{\text {fmax }}$ was as follows:

$$
\text { Ve }(36528)>\mathrm{Bu}(32010)>\operatorname{Ko}(25905)>\mathrm{Wi}(22224)>\mathrm{Do}(18164) \geq \mathrm{Go}\left(16750 \text { seeds m}^{-2}\right) \text {. }
$$

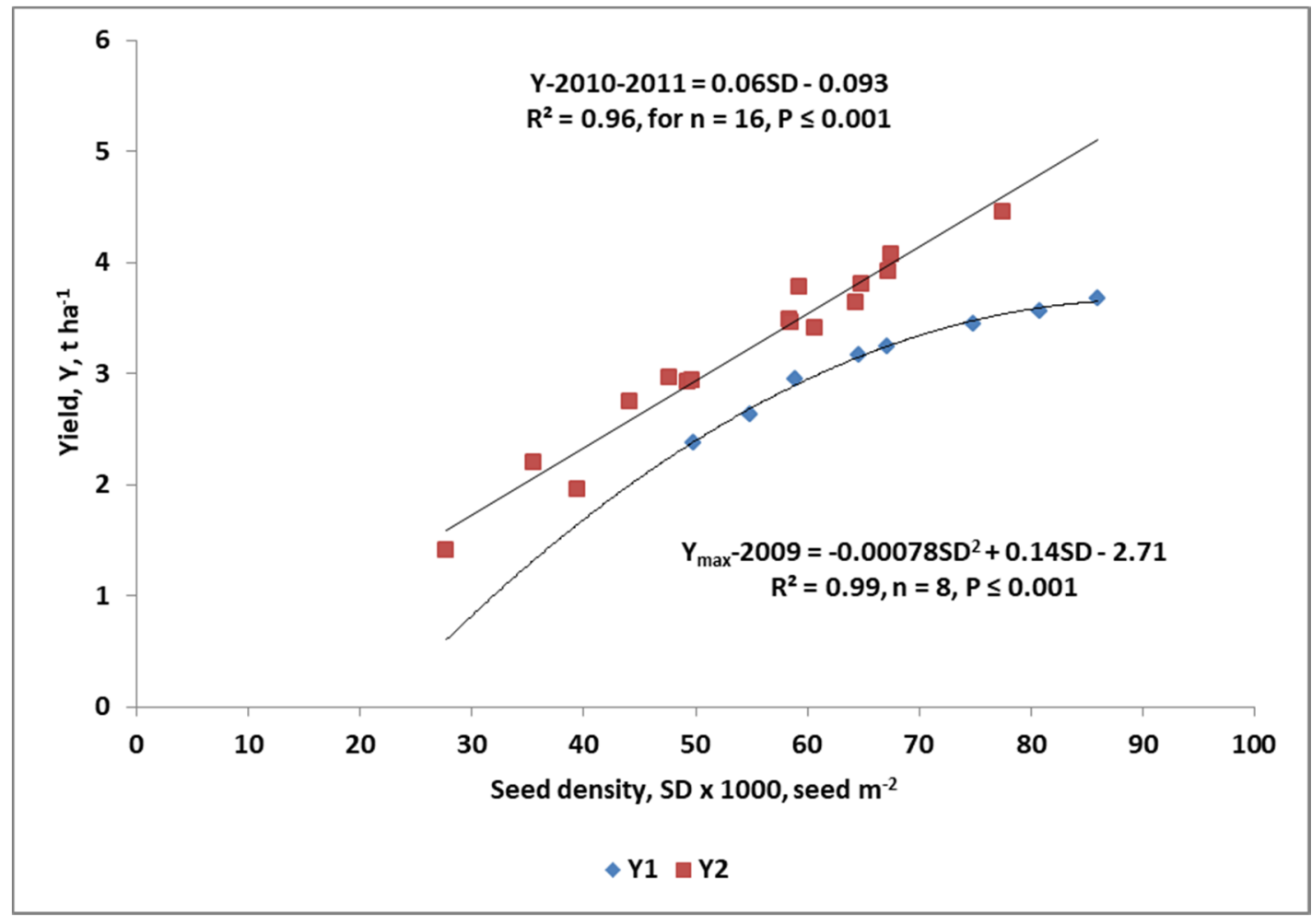

Figure 2. Regression models of seed yield response to seed density in particular years.

The obtained order of sites clearly stresses the impact of $\mathrm{N}_{\mathrm{f}}$ on $\mathrm{SD}$, which was the highest in the most productive sites with respect to the agronomy class, i.e., at $\mathrm{Ve}$, and $\mathrm{Bu}$. However, SD depends not only on the supply of $\mathrm{N}$ but also on the supply of other nutrients such as $\mathrm{K}$ and $\mathrm{Mg}$ during SFP $[25,31,36]$. The final yield of WOSR does not depend only on SD but is significantly corrected by the supply of assimilate to the growing seeds during the SFP [34]. The lower yield, as recorded in 2009, 
irrespective of the site, was due to lower TSW, in spite of a reasonably high SD (Table 3). The observed phenomenon, known as the yield compensation mechanism, can be explained by a natural decrease in radiation use efficiency in WOSR during SFP [37]. In fact, the lower TSW was due to a significantly higher SD, resulting in a dilution of dry matter in the growing seeds.

\subsection{Seed Nitrogen as Yield Driver}

As shown in Figure 1a,b, the amount of $\mathrm{N}$ accumulated in seeds at WOSR harvest, i.e., seed nitrogen $\left(\mathrm{N}_{\mathrm{se}}\right)$, showed the strongest impact on yield. A close relationship was observed between $\mathrm{N}_{\mathrm{se}}$, treated as a single predictor, and yield. The relationship obtained followed the linear regression model:

$$
\mathrm{Y}=0.023 \mathrm{~N}_{\mathrm{se}}+0.685 \text { for } \mathrm{n}=24, \mathrm{R}^{2}=0.92, \text { and } p \leq 0.001
$$

The regression model developed clearly shows that any increase in the $\mathrm{N}_{\text {se }}$ at harvest resulted in the higher yield of seeds. The relationship obtained is corroborated by the simultaneous increase in both $\mathrm{N}_{\mathrm{se}}$ and yield in response to the progressive $\mathrm{N}_{\mathrm{f}}$ rate (Tables 3 and 4 , and Table A3). An $\mathrm{N}_{\mathrm{se}}$ increase is also recorded after application of other nutrients, resulting in an increase of $\mathrm{N}$ content in WOSR seeds [35,38]. As reported by Fordoński et al. [19], the significant relationship between $N_{c}$ in seeds and yield was only found when wheat was a preceding crop for WOSR, but not when this crop followed peas or faba beans. This type of dependency indicates a lower supply of N to WOSR when cereals preceded WOSR. The finding obtained as shown by Equation (16), is indirectly supported by the study by Hoffmann et al. [13], who presented data on $\mathrm{N}_{\mathrm{se}}$, but without an analysis of its relationship with yield. The regression model developed based on Hoffmann's data gave an even better estimation of WOSR yield dependence on $\mathrm{N}_{\text {se }}$ than our own:

$$
\mathrm{Y}=0.038 \mathrm{~N}_{\mathrm{se}}+0.948 \text { for } \mathrm{n}=16, \mathrm{R}^{2}=0.95 \text {, and } p \leq 0.001
$$

The high reliability of these two presented regression models indicates the significant response of $\mathrm{N}_{\mathrm{se}}$ to the applied $\mathrm{N}_{\mathrm{f}}$ rates. There remains, however, a question concerning the yield forming importance of $\mathrm{N}_{\mathrm{se}}$, which summarizes the effect of two components, i.e., $\mathrm{SD}$ and the $\mathrm{N}_{\mathrm{c}}$ in seeds at harvest. As shown in Tables 3 and A1, SD responded significantly to the applied $N_{f}$ rate, but the type of response was site-specific. In four of six sites, the effect of $\mathrm{N}_{\mathrm{f}}$ followed the quadratic regression model, indicating a saturation SD status with respect to the rate of applied $\mathrm{N}_{\mathrm{f}}$. In the other two cases, the $\mathrm{N}_{\mathrm{f}}$ rate was too low to maximize $\mathrm{SD}$, subsequently indicating a shortage of $\mathrm{N}$ supply to the growing pods and seeds during the SFP. This model also indicates a lack of synchronization between the rate of seed growth and the rate of $\mathrm{N}$ remobilization from vegetative WOSR organs during SFP [11]. The $\mathrm{N}_{\mathrm{c}}$ in seeds, with the exception of 2009, increased progressively with the applied $\mathrm{N}_{\mathrm{f}}$ rate. As a result, WOSR seeds in these two years, in spite of the same SD, accumulated significantly more N (Figure 3). The direction coefficient for the 2010/2011 regression model was by 50\% higher as compared to that developed for 2009. The difference obtained indicates, irrespective of weather, a better supply of $\mathrm{N}$ to the growing seeds during SFP, consequently resulting in higher yield (Equation (16). These two models clearly support the hypothesis of the sink strength dominance over the source strength with respect to seed yield [39]. The result obtained clearly demonstrates that WOSR plants well-supplied with $\mathrm{N}$ during the SFP have a potential to minimize the competition for assimilates between growing seeds and their weight (TSW), consequently leading to a higher seed yield [11]. In this study, yield showed, in spite of the important impact of weather in consecutive years, a positive and significant response to all yield components:

$$
\mathrm{Y}=-4.26^{* * *}+0.0002 \mathrm{PD}^{* *}+0.11 \mathrm{Se} / \mathrm{PD}^{* *}+0.0003 \mathrm{SD}^{* * *}+0.61 \mathrm{TSW}{ }^{* * *} \text { for } \mathrm{n}=24, \mathrm{R}^{2}=0.99
$$




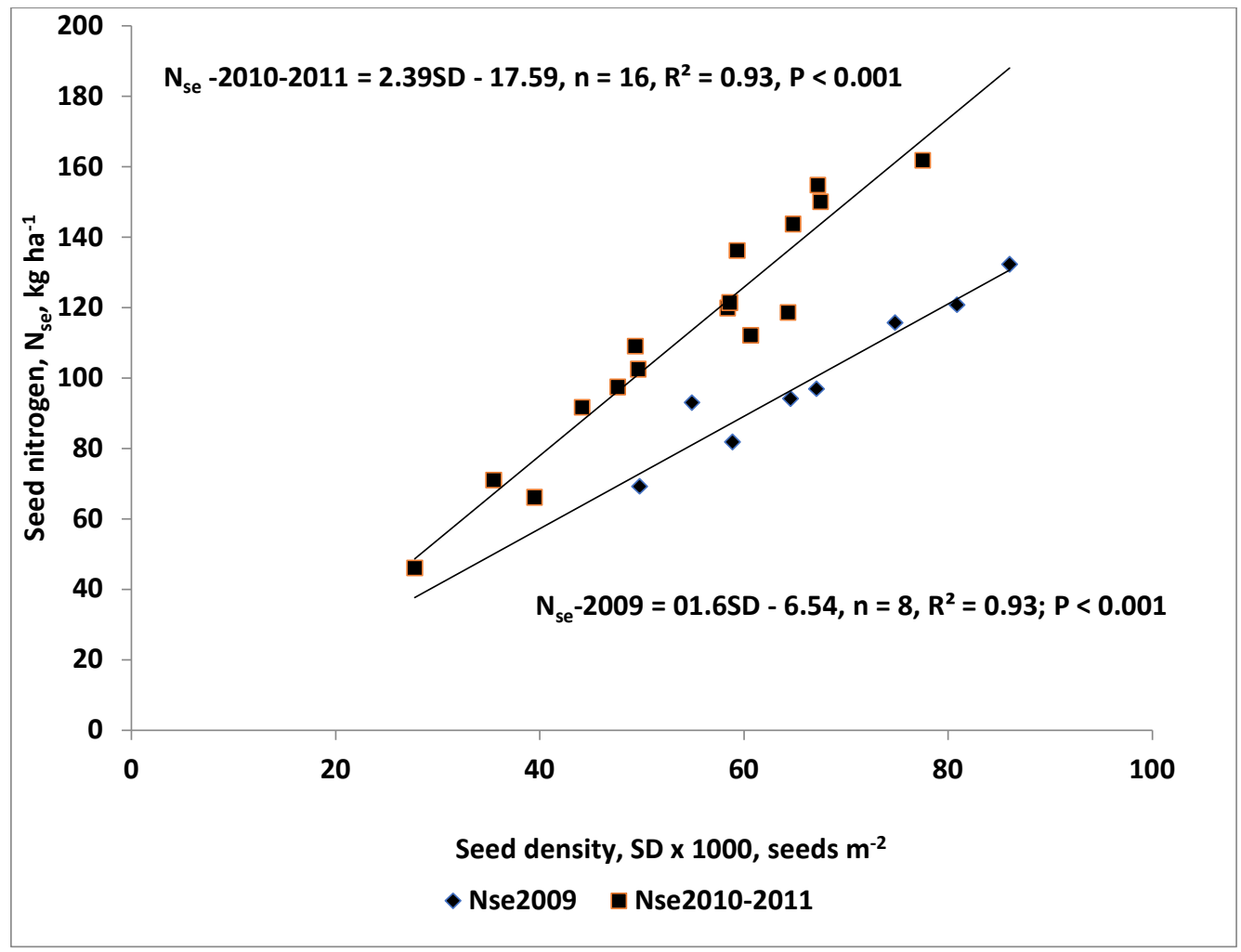

Figure 3. Regression models of seed density impact on the seed nitrogen.

\subsection{Impact of the In-Season N Supply on $N_{s e}$ and Yield}

In this study, it has been assumed that $\mathrm{N}_{\mathrm{se}}$ is significantly affected by the $\mathrm{N}$ supply to WOSR plants during the growing season. The total pool of $\mathrm{N}$, termed as total $\mathrm{N}$ input $\left(\mathrm{N}_{\text {int }}\right)$ is composed of three sub-pools. The first $\mathrm{N}$ source, defined in this study as the $\mathrm{N}$ input $\left(\mathrm{N}_{\mathrm{in}}\right)$, comprised two sub-pools of $\mathrm{N}$. The first one, the indigenous $\mathrm{N}\left(\mathrm{N}_{\mathrm{i}}\right)$, is equal to the $\mathrm{N}_{\text {mins }}$ content in the rooted soil zone in spring $[17,21,23]$. The $\mathrm{N}_{\mathrm{i}}$ affects $\mathrm{N}_{\mathrm{se}}$ on the $\mathrm{N}$-non fertilized plot. The second $\mathrm{N}$ source for WOSR plants during the growing season is equal to the $\mathrm{N}$ dose applied in fertilizer. The third $\mathrm{N}$ pool is the amount of $\mathrm{N}$ released from $\mathrm{N}$ soil resources during WOSR spring vegetation. The maximum $\mathrm{N}_{\mathrm{se}}$ depends, however, on the optimum $\mathrm{N}$ supply to WOSR from all $\mathrm{N}$ pools $\left(\mathrm{N}_{\text {intop }}\right)$ or to its maximum $\left(\mathrm{N}_{\text {intmax }}\right)$ supply. These three $\mathrm{N}$ pools were used as criteria for a site evaluation with respect to $\mathrm{N}_{\mathrm{se}}$ :

(1) $\mathrm{N}_{\text {se }}$ response to $\mathrm{N}_{\mathrm{i}}$ :

Do (102.5) $\geq$ Ko (93.1) > Wi (71.0) $\geq$ Go (66.7) $\geq$ Ve (66.1) > Bu $\left(46.1 \mathrm{~kg} \mathrm{ha}^{-1}\right)$;

(2) $\mathrm{N}_{\text {se }}$ response to $\mathrm{N}_{\text {in }}$, i.e., $\mathrm{N}_{\text {seinop }}$ or $\mathrm{N}_{\text {seinmax }}$ :

Do (153.2) $\geq$ Ve (145.8) > Ko (131.2) $\geq$ Wi (125.2) $\geq \mathrm{Bu}\left(124.2 \mathrm{~kg} \mathrm{ha}^{-1}\right)>\mathrm{Go}\left(95.1, \mathrm{~kg} \mathrm{ha}^{-1}\right)$;

$\left(2^{\prime}\right) \quad \mathrm{N}_{\mathrm{se}}$ net increase with respect to the $\mathrm{N}$ control:

$\mathrm{Ve}(+79.7) \geq \mathrm{Bu}(+78.1)>\mathrm{Wi}(+54.2) \geq \mathrm{Do}(+50.7)>\mathrm{Ko}(+38.1)>\mathrm{Go}\left(+28.4 \mathrm{~kg} \mathrm{ha}^{-1}\right)$;

(1) $\mathrm{N}_{\text {se }}$ response to $\mathrm{N}_{\text {int }}$, i.e., $\mathrm{N}_{\text {seintop }}$ or $\mathrm{N}_{\text {seintmax }}$ :

Do $(162.7) \geq \mathrm{Ve}(152.9)>\mathrm{Ko}(135.1) \geq \mathrm{Bu}(123.0) \geq \mathrm{Wi}(116.4)>\mathrm{Go}\left(91.9, \mathrm{~kg} \mathrm{ha}^{-1}\right)$;

$\left(3^{\prime}\right) \quad \mathrm{N}_{\text {se }}$ net increase with respect to $\mathrm{N}_{\text {in }}$ :

$\mathrm{Do}(+9.5)>\mathrm{Ve}(+7.8)>\mathrm{Ko}(+3.9)>\mathrm{Bu}(-1.2)>\mathrm{Go}(-3.2)>\mathrm{Wi}\left(-8.8 \mathrm{~kg} \mathrm{ha}^{-1}\right)$.

The first row clearly shows that fields at Ko and Do were naturally the most productive, as results from the highest $\mathrm{N}_{\mathrm{se}}$ at harvest. On the opposite site are fields at $\mathrm{Bu}$ and $\mathrm{Ve}$, which increased $\mathrm{N}_{\mathrm{se}}$ the highest in response to $\mathrm{N}_{\mathrm{f}}$ application during the growing season. The third group of sites is 
represented by the field at Go, which showed only a moderate productivity of $\mathrm{N}_{\mathrm{i}}$ and low response to $\mathrm{N}_{\mathrm{f}}$. The highest productivity of $\mathrm{N}$ as recorded in 2011 was due to a high response of $\mathrm{N}_{\text {se }}$ to the amount of $\mathrm{N}$ released from the soil $\mathrm{N}$ resources during the spring growing season. The shortage of $\mathrm{N}$ supply to WOSR plants from the indigenous $\mathrm{N}$ pools during the spring growing season, as recorded for three sites, i.e., Bu, Go, and $\mathrm{Wi}$, resulted in yield stagnation. The results obtained explain the observation presented by Grzebisz et al. [11]. According to these authors, the shortage of N during SFP, leads to an SD decrease, consequently resulting, as shown this study, in a decline of both, i.e., $\mathrm{N}_{\text {se }}$ and yield. This study corroborates the observation by Barłóg and Grzebisz [15], who documented that the $\mathrm{N}_{\mathrm{c}}$ in leaves at the onset of pod growth (BBCH 71) is probably due to a net supply of $\mathrm{N}$ to the growing seeds, which explains $81 \%$ of yield variability.

The $\mathrm{N}_{\text {semax }}$, irrespective of the $\mathrm{N}$ pool, was revealed as a significant discriminator of the studied sites with respect to yield (Table A5). The linear regression model obtained showed the same level of accuracy for $\mathrm{N}_{\text {in }}$ and $\mathrm{N}_{\text {int }}$ in yield prediction (Figure 4). The lowest WOSR yield as a result of low $\mathrm{N}_{\text {semax }}$ was characterized by the field located at Go. The main reason for low $\mathrm{N}_{\text {semax }}$ was the low efficiency of $\mathrm{N}$ in the soil/WOSR system ( $46 \%$ vs. $37 \%$ for $\mathrm{N}_{\text {in }}$ and $\mathrm{N}_{\text {int }}$, respectively). The second group, with a significantly higher $\mathrm{N}_{\text {semax }}$, concomitant with a moderate yield level, comprised three sites, i.e., $\mathrm{Ko}, \mathrm{Bu}$, and $\mathrm{Wi}$. This group was characterized by a high efficiency of $\mathrm{N}_{\text {in }}(60-70 \%)$, but a low efficiency of $\mathrm{N}_{\text {int }}(32-38 \%)$. The gap obtained indicates a low efficiency of $\mathrm{N}$ released from soil $\mathrm{N}$ resources during the growing season. The third group comprised two sites, i.e., Do and Ve, which yielded the highest due to both a much higher $\mathrm{N}_{\text {semax }}$, and $\mathrm{N}_{\text {int }}$ efficiency. The key difference between these two sites resulted from differences in $\mathrm{N}$ efficiency. The field located at Ve was characterized by a moderate use efficiency of $\mathrm{N}_{\mathrm{in}}(58 \%)$, and the field located at Do by the high efficiency of $\mathrm{N}_{\text {int }}(44 \%)$.

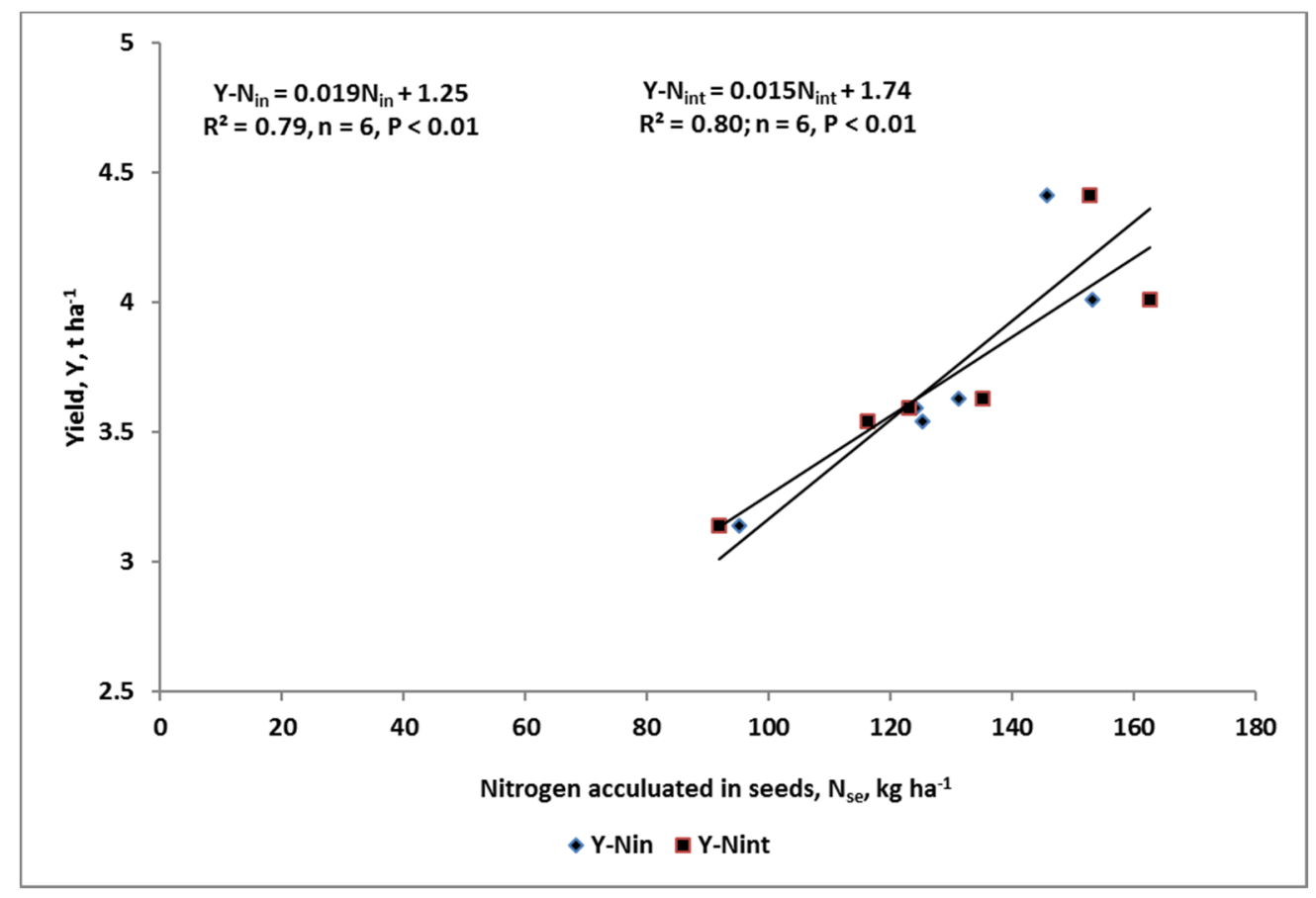

Figure 4. WOSR yield prognosis based on $\mathrm{N}_{\text {semax }}$ calculated for the $\mathrm{N}$ input to the soil/plant system at the beginning of WOSR spring regrowth and its total input.

The next question formulated during the study referred to the applicability of $N_{f}, N_{i n}$, and $N_{\text {int }}$ as yield prognostic tools. Excluding $\mathrm{N}_{\mathrm{f}}$, because its rates were the same in all experiments, the yield prognosis, based on $\mathrm{N}_{\text {in }}$ and $\mathrm{N}_{\text {int }}$, was slightly better for the total $\mathrm{N}$ input:

(1) $\mathrm{N}_{\text {in }}: \mathrm{Y}=-0.000034 \mathrm{~N}_{\text {in }}^{2}+0.0178 \mathrm{~N}_{\text {in }}+1.324$ for $\mathrm{n}=24, \mathrm{R}^{2}=0.48, p \leq 0.05$, 
(2) $\mathrm{N}_{\text {int }}: \mathrm{Y}=0.009 \mathrm{~N}_{\mathrm{inT}}+0.592$ for $\mathrm{n}=24, \mathrm{R}^{2}=0.61, p \leq 0.001$.

The maximum yield, calculated based on equ. 19 , for the $\mathrm{N}_{\text {inop }}$ of $261.8 \mathrm{~kg} \mathrm{ha}^{-1}$ was $3.654 \mathrm{t} \mathrm{ha}^{-1}$. The linear model for $\mathrm{N}_{\text {int }}$ corroborates the importance of $\mathrm{N}$ released during the SFP for exploitation of the WOSR yielding potential due the better supply of $\mathrm{N}$ to the growing seeds.

Nitrogen use efficiency (NUE) can also be used as a criterion for site discrimination with respect to the key yield driving factor, i.e., $\mathrm{N}_{\mathrm{se}}$. The NUE indices as shown in Table 5, in a major part corroborate the opinion expressed by Bouchet et al. [40] about the limited possibility of NUE improvement with respect to the increase of the seed yield of WOSR. The results obtained are in line with this opinion because the developed NUE indices, such as $\mathrm{PFP}_{\mathrm{N}}, \mathrm{AE}_{\mathrm{N}}, \mathrm{PE}_{\mathrm{N}}, \mathrm{R}$ decreased in accordance with the increasing $\mathrm{N}_{\mathrm{f}}$ rate (Table 5). In spite of this, the best criterion for the study site discrimination was the $\mathrm{PFP}_{\mathrm{N}}$, but only for an $\mathrm{N}_{\mathrm{f}}$ rate of $160 \mathrm{~kg} \mathrm{ha}^{-1}$. The order of sites obtained based on the $\mathrm{PFP}_{\mathrm{N} 160}$ was as follows:

Ve (27.9) > Do (24.5) $\geq$ Wi (23.6) $\geq$ Ko (23.0) > Go (18.4) $\geq \mathrm{Bu}(18.3 ; \mathrm{kg}$ seeds kg-1N).

The order obtained was significantly correlated with $\mathrm{N}_{\text {semax }}$, as calculated, based on $\mathrm{N}_{\text {inop/max }}$ or $\mathrm{N}_{\text {intop/max }}$ :

(1) $\mathrm{N}_{\text {in }}: \mathrm{N}_{\text {semax }}=4.279 \mathrm{PFP} \mathrm{N} 160+32.36$ for $\mathrm{n}=6, \mathrm{R}^{2}=0.61, p \leq 0.05$,

(2) $\mathrm{N}_{\text {int }}: \mathrm{N}_{\text {semax }}=5.248 \mathrm{PFP}_{\mathrm{N} 160}+11.65$ for $\mathrm{n}=6, \mathrm{R}^{2}=0.57, p \leq 0.05$.

These two equations are contradictory to the opinion expressed by Bouchet et al. [40]. The relationships obtained clearly showed that $\mathrm{N}_{\mathrm{se}}$ responded positively to the increasing $\mathrm{PFP}_{\mathrm{N}}$, including the site factor. This seemingly contradictory effect of $\mathrm{N}$ fertilizer on WOSR yield and NUE indices indirectly corroborates the hypothesis on $\mathrm{N}_{\mathrm{se}}$ as the driving yield factor. This hypothesis is in accordance with the sink hypothesis presented by Körner [39]. This author clearly stated that sink strength in seed crops is a factor determining the source activity, and the consequent yield. On the other hand, too high $\mathrm{N}_{\mathrm{c}}$ in seeds leads to decline in the crude oil concentration [41].

\section{Conclusions}

The study showed the occurrence of two different season-site $\mathrm{N}$ management strategies, resulting in a significant diversity in SD, the primary yield complement decisive for the final seed yield of WOSR. The first strategy was based on a high indigenous productivity of soil, as revealed in two of the six sites (Ko, Do). The second strategy was based on a high productivity of applied fertilizer N, which was revealed in two sites of the best quality of soil with respect to the soil agronomy class (Ve, $\mathrm{Bu}$ ). The amount of $\mathrm{N}$ accumulated in WOSR seeds at harvest, i.e., seed nitrogen $\left(\mathrm{N}_{\mathrm{se}}\right)$ was found to be the key yield driver factor. Its yield forming function is determined, however, by the SD and the $\mathrm{N}$ content in seeds, which in turn depends on $\mathrm{N}$ supply during SFP. The simultaneous increase of both these components is crucial for yield increase. A sufficiently high amount of $\mathrm{N}_{\text {se }}$ in WOSR seeds during the onset of pod and seed growth can be achieved provided there is a net $\mathrm{N}$ release from its soil resources during the growing season, but especially during SFP. The PFPN is a useful tool for discrimination of site productivity with respect to $\mathrm{N}_{\text {semax }}$, treated as the prerequisite of WOSR yield evaluation.

Author Contributions: Conceptualization, R.Ł. and W.G.; methodology, R.Ł.; software, R.Ł.; validation, W.G.; formal analysis, W.G.; investigation, R.E.; resources, R.Ł.; data curation, W.G.; writing—original draft preparation, R.Ł.; writing-review and editing W.G.; visualization, R.Ł.; supervision, W.G.; project administration, R.Ł. All authors have read and agreed to the published version of the manuscript.

Funding: This publication was co-financed within the framework of Ministry of Science and Higher Education programme as Regional Initiative Excellence" in years 2019-2022. Project No. 005/RID/2018/19.

Acknowledgments: This research was in part supported by UCC Uralchem OJSC.

Conflicts of Interest: The authors declare no conflict of interest. 


\section{Appendix A}

Table A1. Regression patterns of yield, seed density, and $\mathrm{N}$ accumulated in seeds response to the $\mathrm{N}$ fertilizer rate ${ }^{1}, \mathrm{n}=4$.

\begin{tabular}{|c|c|c|c|c|c|c|}
\hline Year & Site & Equation & $\mathbf{R}^{2}$ & $p$ & $\begin{array}{c}\mathrm{N}_{\mathrm{op}} \\
\mathrm{kg} \mathrm{ha}^{-1}\end{array}$ & $\begin{array}{c}\mathrm{Y}_{\max } / \mathrm{SD}_{\max } / \\
\mathrm{N}_{\mathrm{semax}}\end{array}$ \\
\hline \multicolumn{7}{|c|}{ Yield, $\mathrm{Y}, \mathrm{t} \mathrm{ha}^{-1}$} \\
\hline \multirow{2}{*}{2009} & Gostyń, Go & $\mathrm{Y}=-0.00008 \mathrm{~N}_{\mathrm{f}}^{2}+0.017 \mathrm{~N}_{\mathrm{f}}+2.38$ & 0.99 & $\leq 0.001$ & 103.1 & 3.142 \\
\hline & Kołaczkowo, Ko & $\mathrm{Y}=-0.00005 \mathrm{~N}_{\mathrm{f}}^{2}+0.014 \mathrm{~N}_{\mathrm{f}}+2.65$ & 0.94 & $\leq 0.01$ & 142.7 & 3.629 \\
\hline \multirow{2}{*}{2010} & Buszewo, $\mathrm{Bu}$ & $\mathrm{Y}=-0.0002 \mathrm{~N}_{\mathrm{f}}^{2}+0.042 \mathrm{~N}_{\mathrm{f}}+1.41$ & 0.99 & $\leq 0.001$ & 104.3 & 3.589 \\
\hline & Wieszczyn, Wi & $\mathrm{Y}=0.009 \mathrm{~N}_{\mathrm{f}}+2.1$ & 0.91 & $\leq 0.01$ & - & 3.540 \\
\hline \multirow{2}{*}{2011} & Wenecja, Ve & $\mathrm{Y}=0.015 \mathrm{~N}_{\mathrm{f}}+2.01$ & 0.98 & $\leq 0.001$ & - & 4.410 \\
\hline & Donatowo, Do & $\mathrm{Y}=-0.00007 \mathrm{~N}_{\mathrm{f}}^{2}+0.017 \mathrm{~N}_{\mathrm{f}}+2.93$ & 0.99 & $\leq 0.001$ & 128.0 & 4.012 \\
\hline \multicolumn{7}{|c|}{ Seed density, SD, number $\mathrm{m}^{-2}$} \\
\hline \multirow{2}{*}{2009} & Gostyń, Go & $\mathrm{SD}=-1.759 \mathrm{~N}_{\mathrm{f}}^{2}+343.3 \mathrm{~N}_{\mathrm{f}}+49,562$ & 0.97 & $\leq 0.01$ & 97.6 & 66,312 \\
\hline & Kołaczkowo, Ko & $\mathrm{SD}=-0.988 \mathrm{~N}_{\mathrm{f}}^{2}+332 \mathrm{~N}_{\mathrm{f}}+55,707$ & 0.87 & $\leq 0.05$ & 168.1 & 83,612 \\
\hline \multirow{2}{*}{2010} & Buszewo, $\mathrm{Bu}$ & $\mathrm{SD}=-3.09 \mathrm{~N}_{\mathrm{f}}^{2}+629 \mathrm{~N}_{\mathrm{f}}+27,745$ & 0.99 & $\leq 0.001$ & 101.8 & 59,755 \\
\hline & Wieszczyn, Wi & $\mathrm{SD}=138.9 \mathrm{~N}_{\mathrm{f}}+34,135$ & 0.93 & $\leq 0.001$ & - & 56,359 \\
\hline \multirow{2}{*}{2011} & Wenecja, Ve & $\mathrm{SD}=228.3 \mathrm{~N}_{\mathrm{f}}+39,935$ & 0.98 & $\leq 0.001$ & - & 74,463 \\
\hline & Donatowo, Do & $\mathrm{SD}=-0.99 \mathrm{~N}_{\mathrm{f}}^{2}+268.2 \mathrm{~N}_{\mathrm{f}}+49,646$ & 0.99 & $\leq 0.001$ & 135.5 & 67,810 \\
\hline \multicolumn{7}{|c|}{ Nitrogen accumulated in seeds, $\mathrm{N}_{\mathrm{se}}, \mathrm{kg} \mathrm{ha}^{-1}$} \\
\hline \multirow{6}{*}{2009} & Gostyń, Go & $\mathrm{N}_{\mathrm{se}}=-0.0032 \mathrm{~N}_{\mathrm{f}}^{2}+0.59 \mathrm{~N}_{\mathrm{f}}+68.9$ & 0.98 & $\leq 0.001$ & 92,2 & 96.1 \\
\hline & Kołaczkowo, Ko & $\mathrm{N}_{\mathrm{se}}=0.225 \mathrm{~N}_{\mathrm{f}}+95.2$ & 0.87 & $\leq 0.05$ & - & 131.2 \\
\hline & Buszewo, Bu & $\mathrm{N}_{\mathrm{se}}=-0.0064 \mathrm{~N}_{\mathrm{f}}^{2}+1.41 \mathrm{~N}_{\mathrm{f}}+46.3$ & 0.99 & $\leq 0.001$ & 110.3 & 124.2 \\
\hline & Wieszczyn, Wi & $\mathrm{N}_{\mathrm{se}}=0.368 \mathrm{~N}_{\mathrm{f}}+66.0$ & 0.85 & $\leq 0.05$ & - & 124.9 \\
\hline & Wenecja, Ve & $\mathrm{N}_{\mathrm{se}}=0.558 \mathrm{~N}_{\mathrm{f}}+64.5$ & 0.95 & $\leq 0.001$ & - & 153.8 \\
\hline & Donatowo, Do & $\mathrm{N}_{\mathrm{se}}=-0.0022 \mathrm{~N}_{\mathrm{f}}^{2}+0.67 \mathrm{~N}_{\mathrm{f}}+102.8$ & 0.99 & $\leq 0.001$ & 152.7 & 154.1 \\
\hline
\end{tabular}


Table A2. Matrix of Spearman's correlation coefficients between yield components and indices of N management by WOSR, $\mathrm{n}=24$.

\begin{tabular}{|c|c|c|c|c|c|c|c|c|c|c|c|c|c|}
\hline Characteristics & S TB & $\mathrm{HI}$ & PD & $\mathrm{Se} / \mathrm{Po}$ & SD & TSW & $\mathbf{N}_{\mathrm{c}}$ & $\mathbf{N}_{\text {se }}$ & $\mathbf{N}_{\mathbf{r}}$ & TN & NHI & UNA & UNP \\
\hline $\mathrm{Y}$ & $0.56^{* *}$ & 0.19 & $0.65^{* *}$ & -0.00 & $0.84^{* * *}$ & 0.19 & 5473 & $0.96^{* * *}$ & $0.47^{*}$ & $0.83^{* * *}$ & -0.00 & 0.18 & -0.26 \\
\hline TB & 1.00 & $-0.67^{* * *}$ & 0.63 ** & -0.29 & $0.62 * *$ & -0.06 & 0.24 & 0.49 * & $0.91^{* * *}$ & $0.83^{* * *}$ & $-0.69 * * *$ & $0.74^{* * *}$ & $-0.70^{* * *}$ \\
\hline $\mathrm{HI}$ & & 1.00 & -0.23 & $0.42 *$ & -0.01 & 0.24 & 0.16 & 0.25 & -0.63 ** & -0.24 & $0.84^{* * *}$ & $-0.70 * * *$ & $0.64^{* *}$ \\
\hline PD & & & 1.00 & $-0.63 * *$ & $0.71^{* * *}$ & -0.19 & -0.06 & $0.47^{*}$ & 0.36 & $0.48^{*}$ & -0.17 & 0.09 & -0.12 \\
\hline $\mathrm{Se} / \mathrm{Po}$ & & & & 1.00 & 0.06 & -0.12 & 0.37 & 0.16 & -0.07 & 0.05 & 0.24 & -0.05 & 0.04 \\
\hline SD & & & & & 1.00 & -0.35 & 0.30 & $0.76^{* * *}$ & 0.49 & $0.73^{* * *}$ & -0.09 & 0.17 & -0.21 \\
\hline $\mathrm{N}$ & & & & & & & 1.00 & $0.75^{* * *}$ & 0.36 & $0.65^{* *}$ & -0.01 & $0.43 *$ & $-0.51 *$ \\
\hline $\mathrm{N}_{\mathrm{se}}$ & & & & & & & & 1.00 & $0.46^{*}$ & $0.85^{* * *}$ & 0.03 & 0.25 & -0.34 \\
\hline $\mathrm{Nr}$ & & & & & & & & & 1.00 & $0.86^{* * *}$ & $-0.82 * * *$ & $0.91^{* * *}$ & $-0.87^{* * *}$ \\
\hline $\mathrm{TN}$ & & & & & & & & & & 1.00 & $-0.48^{*}$ & $0.69 * * *$ & $-0.72^{* * *}$ \\
\hline $\mathrm{NHI}$ & & & & & & & & & & & 1.00 & $-0.87^{* * *}$ & $0.86^{* * *}$ \\
\hline UNA & & & & & & & & & & & & 1.00 & $-0.95^{* * *}$ \\
\hline
\end{tabular}

******* indicate significant differences at $p<0.001, p<0.01$, and $p<0.05$. Y—seed yield; TB-total biomass; HI-harvest index; PD-pod density; Se/Po—number of seeds per pod; SD—seed density; TSW—thousand seed weight; $\mathrm{N}_{\mathrm{c}}-\mathrm{N}$ concentration in seeds; $\mathrm{N}_{\mathrm{se}}$-amount of $\mathrm{n}$ accumulated in seeds; $\mathrm{N}_{\mathrm{r}}$-amount of $\mathrm{n}$ in WOSR post-harvest residues; TN-total $\mathrm{N}$ in WOSR biomass at harvest; $\mathrm{NHI}$-nitrogen harvest index; UNA — unit N accumulation; UNP—unit N productivity. 
Table A3. Spearman's correlation matrix between yield components, selected nitrogen variables and PCA factors.

\begin{tabular}{ccccc}
\hline Variables & F1 & F2 & F3 & F4 \\
\hline Y & $\mathbf{0 . 9 \mathbf { 1 } ^ { \mathbf { 1 } }}$ & -0.11 & -0.05 & -0.27 \\
$\mathrm{PD}$ & 0.60 & $-\mathbf{0 . 7 7}$ & 0.18 & -0.05 \\
$\mathrm{Se} / \mathrm{Po}$ & 0.02 & 0.66 & $-\mathbf{0 . 7 4}$ & 0.01 \\
$\mathrm{SD}$ & $\mathbf{0 . 8 3}$ & -0.38 & -0.39 & 0.03 \\
$\mathrm{TSW}$ & 0.16 & 0.55 & 0.68 & -0.42 \\
$\mathrm{~N}$ & 0.68 & 0.64 & 0.01 & -0.05 \\
$\mathrm{~N}_{\text {se }}$ & $\mathbf{0 . 9 5}$ & 0.14 & -0.07 & -0.25 \\
$\mathrm{TN}$ & $\mathbf{0 . 9 5}$ & 0.10 & 0.08 & 0.26 \\
UNA & 0.45 & 0.27 & 0.34 & $\mathbf{0 . 7 8}$ \\
\hline
\end{tabular}

${ }^{1}$ bold = correlation coefficients for $\mathrm{R}^{2} \geq 0.50$. Y—seed; yield; PD—pod density; Se/Po—number of seeds per pod; $\mathrm{SD}$ - seed density; TSW—-thousand seed weight; $\mathrm{N}-\mathrm{N}$ content in seeds; $\mathrm{N}_{\mathrm{se}}$-amount of $\mathrm{n}$ accumulated in seeds; TN—total N in WOSR biomass at harvest; NHI—nitrogen harvest index; UNA—unit N accumulation.

Table A4. Regression patterns of key WOSR nitrogen management characteristics response to the N fertilizer rate, $\mathrm{n}=4$.

\begin{tabular}{|c|c|c|c|c|c|c|}
\hline Year & Site & Equation & $\mathbf{R}^{2}$ & $p$ & $\underset{\mathrm{kg} \mathrm{hap}^{-1}}{\mathrm{~N}_{\text {op }}}$ & $\begin{array}{c}\mathbf{N}_{\text {inmax }} / \\
\mathbf{N}_{\text {gainmax }} / \\
\mathbf{N}_{\text {intmax }}\end{array}$ \\
\hline \multicolumn{7}{|c|}{$\mathrm{N}_{\text {input }}, \mathrm{N}_{\text {in }}, \mathrm{kg} \mathrm{ha}^{-1}$} \\
\hline \multirow{2}{*}{2009} & Gostyń, Go & $\mathrm{N}_{\mathrm{in}}=-0.0033 \mathrm{~N}_{\mathrm{f}}^{2}+1.36 \mathrm{~N}_{\mathrm{f}}+42.5$ & 0.98 & $\leq 0.001$ & 206.2 & 182.8 \\
\hline & Kołaczkowo, Ko & $\mathrm{N}_{\text {in }}=0.225 \mathrm{~N}_{\mathrm{f}}+88.1$ & 0.89 & $\leq 0.05$ & - & 124.1 \\
\hline \multirow{2}{*}{2010} & Buszewo, Bu & $\mathrm{N}_{\mathrm{in}}=-0.006 \mathrm{~N}_{\mathrm{f}}^{2}+2.26 \mathrm{~N}_{\mathrm{f}}+74.7$ & 0.99 & $\leq 0.001$ & 176.3 & 273.7 \\
\hline & Wieszczyn, Wi & $\mathrm{N}_{\text {in }}=0.37 \mathrm{~N}_{\mathrm{f}}+47.9$ & 0.85 & $\leq 0.05$ & - & 107.1 \\
\hline \multirow{2}{*}{2011} & Wenecja, Ve & $\mathrm{N}_{\text {in }}=0.57 \mathrm{~N}_{\mathrm{f}}-5.27$ & 0.95 & $\leq 0.001$ & - & 85.9 \\
\hline & Donatowo, Do & $\mathrm{N}_{\mathrm{se}}=-0.0022 \mathrm{~N}_{\mathrm{f}}^{2}+20.91 \mathrm{~N}_{\mathrm{f}}+59.1$ & 0.99 & $\leq 0.001$ & 207.5 & 154.1 \\
\hline \multicolumn{7}{|c|}{$\mathrm{N}_{\text {gain }}, \mathrm{kg} \mathrm{ha}^{-1}$} \\
\hline \multirow{2}{*}{2009} & Gostyń, Go & $\mathrm{N}_{\text {gain }}=-0.73 \mathrm{~N}_{\mathrm{f}}^{2}+0.78 \mathrm{~N}_{\mathrm{f}}+31.5$ & 0.99 & $\leq 0.001$ & 53.5 & 52.4 \\
\hline & Kołaczkowo, Ko & $\mathrm{N}_{\text {gain }}=-0.62 \mathrm{~N}_{\mathrm{f}}+229.6$ & 0.96 & $\leq 0.001$ & - & 129.6 \\
\hline \multirow{2}{*}{2010} & Buszewo, Bu & $\mathrm{N}_{\text {gain }}=-0.014 \mathrm{~N}_{\mathrm{f}}^{2}+1.75 \mathrm{~N}_{\mathrm{f}}+104.8$ & 0.97 & $\leq 0.001$ & 64.8 & 161.6 \\
\hline & Wieszczyn, Wi & $\mathrm{N}_{\text {gain }}=-0.0057 \mathrm{~N}_{\mathrm{f}}^{2}+0.62 \mathrm{~N}_{\mathrm{f}}+186.2$ & 0.52 & $\leq 0.05$ & 54.4 & 169.3 \\
\hline \multirow{2}{*}{2011} & Wenecja, Ve & $\mathrm{N}_{\text {gain }}=-0.111 \mathrm{~N}_{\mathrm{f}}+135$ & 0.52 & $\leq 0.05$ & - & 117.2 \\
\hline & Donatowo, Do & $\mathrm{N}_{\text {gain }}=-0.381 \mathrm{~N}_{\mathrm{f}}+203.3$ & 0.89 & $\leq 0.05$ & - & 142.3 \\
\hline \multicolumn{7}{|c|}{$\mathrm{N}_{\text {input total }}, \mathrm{N}_{\text {int }}, \mathrm{kg} \mathrm{ha}^{-1}$} \\
\hline \multirow{2}{*}{2009} & Gostyń, Go & $\mathrm{N}_{\text {int }}=-0.007 \mathrm{~N}_{\mathrm{f}}^{2}+1.78 \mathrm{~N}_{\mathrm{f}}+140.7$ & 0.99 & $\leq 0.001$ & 122.0 & 249.4 \\
\hline & Kołaczkowo, Ko & $\mathrm{N}_{\text {int }}=0.375 \mathrm{~N}_{\mathrm{f}}+289$ & 0.89 & $\leq 0.05$ & - & 349.0 \\
\hline \multirow{2}{*}{2010} & Buszewo, Bu & $\mathrm{N}_{\text {int }}=-0.0135 \mathrm{~N}_{\mathrm{f}}^{2}+2.75 \mathrm{~N}_{\mathrm{f}}+171$ & 0.99 & $\leq 0.001$ & 101.9 & 311.0 \\
\hline & Wieszczyn, Wi & $\mathrm{N}_{\text {int }}=-0.006 \mathrm{~N}_{\mathrm{f}}^{2}+1.62 \mathrm{~N}_{\mathrm{f}}+235$ & 0.83 & $\leq 0.05$ & 142.4 & 344.6 \\
\hline \multirow{2}{*}{2011} & Wenecja, Ve & $\mathrm{N}_{\text {int }}=0.89 \mathrm{~N}_{\mathrm{f}}+240$ & 0.99 & $\leq 0.001$ & - & 382.4 \\
\hline & Donatowo, Do & $\mathrm{N}_{\text {int }}=0.619 \mathrm{~N}_{\mathrm{f}}+258.3$ & 0.95 & $\leq 0.05$ & - & 357.3 \\
\hline
\end{tabular}


Table A5. Regression patterns of key WOSR $\mathrm{N}_{\text {se }}$ response to the $\mathrm{N}$ supply, $\mathrm{n}=4$.

\begin{tabular}{cccccccc}
\hline \multirow{2}{*}{ Year } & Site & Equation & $\mathbf{R}^{2}$ & $p$ & $\begin{array}{c}\mathbf{N}_{\text {inop/ }} \mathbf{N}_{\text {inmax }} \\
\text { kg ha }\end{array}$
\end{tabular}

${ }^{1} \mathrm{NE}-$ nitrogen efficiency.

\section{References}

1. Abbadi, A.; Leckband, G. Rapessed breeding for oil content, quality, and sustainability. Eur. J. Lipid Sci. Technol. 2011, 113, 1198-1206. [CrossRef]

2. Vinnichek, L.; Pogorelova, E.; Dergunov, A. Oilseed market: Global trends. IOP Conf. Ser. Earth Environ. Sci. 2019, 274, 0112030. [CrossRef]

3. FAOSTAT. Food and Agriculture Organization of the United Nations. Available online: http://faostat.fao.org/ site/567/default.aspx\#ancor (accessed on 25 June 2020).

4. Zając, T.; Klimek-Kopyra, A.; Oleksy, A.; Lorenc-Kozik, A.; Ratajczak, K. Analysis of yield and plant traits of oilseed rape (Brassica napus L.) cultivated in temperate region in light of the possibilities of sowing in arid areas. Acta Agrobotanica 2016, 69, 1696. [CrossRef]

5. Carre, P.; Pouzet, A. Rapeseed market, worldwide and in Europe. Ocl 2014, 21, D102. [CrossRef]

6. Pullens, J.W.M.; Sharif, B.; Trnka, M.; Balek, J.; Semenov, M.A.; Olesen, J.E. Risk factors for European winter oilseed rape production under climate change. Agric. For. Meteorol. 2019, 272, 30-39. [CrossRef]

7. Brown, J.K.; Beeby, R.; Penfield, S. Yield instability of winter oilseed rape modulated by early winter temperature. Sci. Rep. 2019, 9, 6953. [CrossRef]

8. Sieling, K.; Böttcher, U.; Kage, H. Effect of sowing method and N application on seed yield and N use efficiency of winter oilseed rape. Agronomy 2017, 7, 21. [CrossRef]

9. Diepenbrock, W. Yield analysis of winter oilseed rape (Brassica napus L.): A review. Field Crops Res. 2000, 67, 35-49. [CrossRef]

10. Habekotté, B. Quantitative analysis of pod formation, seed set and seed filling in winter oilseed rape (Brassica napus L.) under field conditions. Field Crops Res. 1993, 35, 21-33. [CrossRef]

11. Grzebisz, W.; Szczepaniak, W.; Grześ, S. Sources of nutrients for high-yielding winter oilseed rape (Brassica napus L.) during post-flowering growth. Agronomy 2020, 10, 626. [CrossRef]

12. Berry, P.M.; Spink, J.H. A physiological basis of oilseed rape yields: Past and future. J. Agric. Sci. 2006, 144, 381-392. [CrossRef]

13. Hoffmann, M.P.; Jacobs, A.; Whitbread, A.M. Crop modeling based analysis of site-specific production limitations of winter oilseed rape in northern Germany. Field Crops Res. 2015, 178, 49-62. [CrossRef]

14. Weymann, W.; Böttcher, U.; Sieling, K.; Kage, H. Effects of weather conditions during different growth phases on yield formation of winter oilseed rape. Field Crops Res. 2015, 173, 41-48. [CrossRef] 
15. Barłóg, P.; Grzebisz, W. Effect of timing and nitrogen fertilizer application on winter oilseed rape (Brassica napus L.). II. Nitrogen uptake dynamics and fertilizer efficiency. J. Agron. Crop. Sci. 2004, 190, 314-323. [CrossRef]

16. Sieling, K.; Kage, H. Efficient N management using winter oilseed rape. A review. Agron. Sustain. Dev. 2010, 30, 271-279. [CrossRef]

17. Barraclough, P.B. Root growth, macro-nutrient uptake dynamics and soil fertility requirements of a high-yielding winter oilseed rape crop. Plant Soil 1989, 119, 59-70. [CrossRef]

18. Li, H.; Cong, R.; Ren, T.; Li, X.; Ma, C.; Zheng, L.; Zhang, Z.; Lu, J. Yield response to $n$ fertilizer and optimum $\mathrm{N}$ rate of winter oilseed rape under different soil indigenous $\mathrm{N}$ supplies. Field Crops Res. 2015, 181, 52-59. [CrossRef]

19. Fordoński, G.; Pszczółkowska, A.; Okorski, A.; Olszewski, J.; Załuski, D.; Gorzkowska, A. The yield and chemical composition of winter oilseed rape seeds depending on different nitrogen fertilization rates and preceding crop. J. Elem. 2016, 21, 1225-1234.

20. Olfs, H.-W.; Blankenau, K.; Brentrup, F.; Jasper, J.; Link, A.; Lammel, J. Soil- and plant-based nitrogen-fertilizer recommendations in arable farming. J. Plant Nutr. Soil Sci. 2005, 168, 414-431. [CrossRef]

21. Barłóg, P.; Łukowiak, R.; Grzebisz, W. Predicting the content of soil mineral nitrogen based on the content of calcium chloride-extractable nutrients. J. Plant Nutr. Soil Sci. 2017, 180, 624-635. [CrossRef]

22. Li, H.; Lu, J.; Ren, T.; Li, X.; Cong, R. Nutrient efficiency of winter oilseed rape in an intensive cropping system: A regional analysis. Pedosphere 2017, 27, 364-370. [CrossRef]

23. Łukowiak, R.; Barłóg, P.; Grzebisz, W. Soil mineral nitrogen and the rating of $\mathrm{CaCl}_{2}$ extractable nutrients. Plant Soil Environ. 2017, 63, 177-183.

24. Grzebisz, W.; Szczepaniak, W.; Barłóg, P.; Przygocka-Cyna, K.; Potarzycki, J. Phosphorus sources for winter oilseed rape (Brassica napus L.)-Magnesium sulfate management impact on P use efficiency. Arch. Agron. Soil Sci. 2018, 12, 1646-1662. [CrossRef]

25. Szczepaniak, W.; Grzebisz, W.; Potarzycki, J.; Łukowiak, R.; Przygocka-Cyna, K. Nutritional status of winter oilseed rape in cardinal stages of growth as yield indicator. Plant Soil Environ. 2015, 61, 291-296. [CrossRef]

26. Grzebisz, W.; Łukowiak, R.; Sassenrath, G. Virtual nitrogen as a tool for assessment of nitrogen at the field scale. Field Crops Res. 2018, 218, 182-184. [CrossRef]

27. Bardsley, C.E.; Lancaster, J.D. Determination of reserve sulfur and soluble sulfates in soils. Soil Sci. Soc. Am. Proc. 1980, 24, 265-268. [CrossRef]

28. Fotyma, E.; Fotyma, M.; Pietruch, C. The content of mineral N in arable soils in Poland. Fertil. Fertil. 2004, VI, 11-54.

29. Cassman, G.; Dobermann, A.; Walters, D. Agro-ecosystems, nitrogen-use efficiency, and nitrogen Management. AMBIO 2002, 31, 132-140. [CrossRef]

30. Rathke, G.W.; Christen, O.; Diepenbrock, W. Effects of nitrogen source and rate on productivity and quality of winter oilseed rape (Brassica napus L.) grown in different crop rotations. Field Crops Res. 2005, 94, 103-113. [CrossRef]

31. Wang, X.; Mathieu, A.; Cournede, P.-H.; Allirand, J.-M.; Jullien, A.; de Reffye, P.; Zhang, B.G. Variability and regulation of the number of ovules, seeds, and pods according to assimilate availability in winter oilseed rape (Brassica napus L.). Field Crops Res. 2011, 122, 60-69. [CrossRef]

32. Wang, Y.; Liu, T.; Li, X.; Ren, T.; Cong, R.; Lu, J. Nutrient deficiency limits population development, yield formation and nutrient uptake of direct sown winter oilseed rape. J. Integr. Agric. 2015, 14, 670-680. [CrossRef]

33. Szczepaniak, W. A mineral profile of winter oilseed rape in critical stages of growth-Nitrogen. J. Elem. 2014, 19, 759-778. [CrossRef]

34. Gomez, N.; Miralles, D.J. Factors that modify early and late reproductive phases in oilseed rape (Brassica napus L.): Its impact on seed yield and oil content. Ind. Crops Prod. 2011, 34, 1277-1285. [CrossRef]

35. Jankowski, K.J.; Hulanicki, P.S.; Krzebietke, S.; Żarczyński, P.; Hulanicki, P.; Sokólski, M. Yield and quality of winter oilseed rape in response to different systems of foliar fertilization. J. Elem. 2016, 21, 1017-1027. [CrossRef]

36. Pan, Y.; Lu, Z.; Lu, J.; Li, X.; Cong, R. Effects of low sink demand on leaf photosynthesis under potassium deficiency. Plant Physiol. Biochem. 2017, 113, 110-121. [CrossRef] [PubMed] 
37. Dreccer, M.F.; Schapendonk, A.H.; Slafer, G.A.; Rabbinge, R. Comparative response of wheat and oilseed rape to nitrogen supply: Absorption and utilization efficiency of radiation and nitrogen during the reproductive stages of growth. Plant Soil 2000, 220, 189-205. [CrossRef]

38. Grzebisz, W.; Łukowiak, R.; Biber, M.; Przygocka-Cyna, K. Effect of multi-micronutrient fertilizers applied to foliage on nutritional status of winter oilseed rape and development of yield forming elements. J. Elem. 2010, 15, 477-491. [CrossRef]

39. Körner, C. Paradigm shift in plant growth control. Curr. Opin. Plant Biol. 2015, 25, 107-114. [CrossRef]

40. Bouchet, A.-S.; Laperche, A.; Bissuel-Belaygue, C.; Snowdon, R.; Nesi, N.; Stahl, A. Nitrogen use eficiency in rapeseed. A review. Agron. Sustain. Dev. 2016, 36, 38. [CrossRef]

41. Szczepaniak, W.; Grzebisz, W.; Barłóg, P.; Przygocka-Cyna, K. Mineral composition of winter oilseed rape (Brassica napus L.) seeds as a tool for oil seed prognosis. J. Cen. Eur. Agric. 2017, 18, 196-213. [CrossRef]

(C) 2020 by the authors. Licensee MDPI, Basel, Switzerland. This article is an open access article distributed under the terms and conditions of the Creative Commons Attribution (CC BY) license (http://creativecommons.org/licenses/by/4.0/). 